\title{
Locating Hotspots for the Social Life Cycle Assessment of Bio-Based Products from Short Rotation Coppice
}

\author{
Daniela Fürtner $^{1} \cdot$ Lea Ranacher $^{1}$ • E. Alejandro Perdomo Echenique ${ }^{1}$ Peter Schwarzbauer ${ }^{2}$. Franziska Hesser ${ }^{1,2}$
}

Received: 8 July 2020 / Accepted: 17 February 2021 / Published online: 25 March 2021

(C) The Author(s) 2021

\begin{abstract}
The establishment of new value chains raises expectations in economic and social benefits. To determine whether these expectations can be fulfilled or whether there are also negative consequences, social aspects should be assessed as early as the R\&D phase. Potential social impacts can be assessed with the help of a social life cycle assessment (SLCA). A common problem in SLCA studies is the large number of social aspects. Thus, it is important to prioritize the most relevant aspects. Scholars agree that socioeconomic indicators should not be selected on a purely intuitive and common sense basis and that a standardized approach is missing. A three-step process has been developed to identify the most vulnerable and relevant social aspects. These three steps were implemented into a case study to empirically test the method. Short-rotation-coppice as an alternative form of agricultural dendromass production is one possibility to obtain wood resources for the processing of bio-based products. The use of agricultural land for dendromass production promises additional income for the region's farmers and job opportunities for the local population. The extant literature shows that the most frequently addressed impacts are related to workers' health and safety aspects. The outcome of this study aims to support future research by identifying an appropriate approach for the selection of indicators in SLCA. For studies with a similar focus, the proposed set of indicators can be used as a framework in itself or serve as a basis for the choice of relevant social indicators.
\end{abstract}

Keywords Social life cycle assessment SLCA bio-based products $\cdot$ Socioeconomic impacts $\cdot$ Socioeconomic indicators . Indicator selection $\cdot$ Stakeholder analysis

\section{Introduction}

The emerging bioeconomy is seen as one of the major drivers in climate change mitigation and for the development of a more sustainable future. In the context of this paper, the bioeconomy is understood as defined by the European Union [1] in their bioeconomy strategy — covering "all sectors and systems that rely on biological resources (animals, plants, microorganisms, and derived biomass, including organic waste), their functions, and principles (including all primary

Franziska Hesser

franziska.hesser@boku.ac.at

1 Wood K plus-Competence Center for Wood Composites and Wood Chemistry, Kompetenzzentrum Holz GmbH, Altenberger Straße 69, 4040 Linz, Austria

2 Department of Economics and Social Sciences, Institute of Marketing and Innovation, University of Natural Resources and Life Sciences Vienna, Gregor-Mendel-Straße 33, 1180 Vienna, Austria production sectors that use and produce biological resources (agriculture, forestry, fisheries, and aquaculture)." Costefficiency and sustainability of bio-based value chains are both strongly linked to regional feedstock availability. Spatial proximity of feedstock production, as provided by Short Rotation Coppice (SRC) dendromass production, may have positive impacts on transportation costs and the environment [2]. Ensuring sustainable development of evolving value chains requires an accompanying sustainability assessment, which provides information about (potential) sustainability implications. For a holistic view on sustainability, a life cycle approach has to comprise all three fields of sustainability: environment, economic, and social [3]. An established technique for sustainability assessment of longstanding development is life cycle assessment (LCA), as one of the most frequently used methods [4].

New value chains, as aimed for in the bioeconomy ("knowledge-based bioeconomy"), are a young field of research, and knowledge about the social dimension of the related production processes is limited. The increasing interest in bio-based products requires a precise monitoring of 
entailing the social or socioeconomic impacts. Information on important social aspects allows decision- and policy-makers to improve the social performance and prevent undesirable social implications. Regarding bio-based value chains, a high social risk potential is assumed for the upstream processes in the agricultural sector [5]. However, comparison of social impacts is especially challenging for bio-based value chains, since socioeconomic effects are strongly dependent on several production factors like the cultivation method, land quality, and the production scale [6]. In addition, through the relation to the spatial context, the effects have a strong regional dependency, since socioeconomic impacts have an influence on the respective environment of production locations [7]. In the case of bio-based products from SRC, two points are striking: studies regarding the production method SRC as well as regarding the geographical scope of interest, Eastern Europe or specifically Slovakia, are missing.

A method suitable for this purpose is social life cycle assessment (SLCA), analogous to conventional LCA for the assessment of environmental implications. SLCA is an ISOcompliant technique for the assessment of (potential) social impacts with the aim to assess "social and socioeconomic aspects of products [and services] and their potential positive and negative impacts along their life cycle encompassing" all stages of a products' life cycle from "cradle to grave," including raw material extraction, manufacturing, distribution, use, re-use, maintenance, as well as recycling and final disposal as stated by Benoit et al. [8]. The underlying goal of SLCA is to foster the area of protection (AoP), which is usually human dignity and well-being [9]. Human well-being is defined by social, human, physical, financial, and natural capital, which contribute to the present and future well-being of individuals [9]. However, SLCA is, in contrast to LCA, a very young field of research and still under development. Although LCA and SLCA differ in many aspects, the development of the SLCA method seeks to follow the same structure as proposed for LCA in ISO 14040 and ISO 14044, comprising goal and scope definition, inventory analysis, impact assessment, and interpretation of the results [8].

Due to many years of focusing on environmental and economic aspects, social impacts are still under-investigated, which also concerns the social performance in the production of bio-based products [5]. So far, information about social aspects that are relevant to be considered in SLCA is lacking. As a consequence of the large number of socioeconomic impacts that may arise, the impact categories must be adapted to the individual case. Besides data collection, a research design for a socioeconomic assessment must be created with emphasis on expressive and comprehensive indicators, which is a challenging [10] but crucial and vitally important part in SLCA [11]. There is no standardized method for the selection of indicators in SLCA. Therefore, several experience-based approaches are used to make a selection. Indicators need to be individually adapted, since socioeconomic effects vary strongly across projects or cases, depending on different factors [12]. Especially the implementation of bioeconomy strategies requires a regional context-specific approach [13], which determines social aspects that are of core interest for potentially affected stakeholders.

Benoît et al. [8] provide an overview of social aspects related to five different stakeholder groups that should be addressed in an SLCA in the "Guidelines for SLCA of products" (referred to as UNEP/SETAC Guidelines in the remaining study). In literature, the terms social issues, effects, impact categories, subcategories, and indicators are used but cannot always be clearly defined as their conceptualization is quite diverse. Falcone et al. [14] described indicators as a bridge linking subcategories and impact categories. A standardization of the terms, as already stated by Kühnen and Hahn [15] as well as by Martin et al. [16], would be necessary for easier and more efficient orientation in the jungle of social aspects. A range of terms frequently used in relation to SLCA indicators was identified. Table 1 gives a range of definitions of these terms in order to enable a deeper understanding of them.

For simplicity, the term social aspect is used as an overall description of anything related to human well-being, based on the explanation by Siebert et al. [19]. Furthermore, the terms social (impact) category and subcategory will not be divided, as a precise distinction between terms cannot be guaranteed. However, an exception would be the use of citations and discussion of literature, to not misrepresent statements of other authors. In this manner, the terms social and socioeconomic will be conflated, as their differences are not always obvious. For a more fluent reading experience, the terms aspects, impact categories and indicators are prefaced by social only.

All these terms can address negative and positive impacts. Regarding a sufficient SLCA, positive impacts should be assessed that go beyond compliance stipulated by laws [8]. Positive social impacts are often underrepresented in SLCA studies [24], but have recently received more attention, for example, from Ekener et al. [25] or Benoît-Norris et al. [26]. Positive social impacts are also known as social handprints, as proposed by Norris [27]. The major difference between LCA and SLCA lies in the possibility to also assess positive impacts in SLCA, which are always directly related to people who are (potentially) affected by these impacts. Thus, one of the most important questions is, which groups of people are (potentially) affected. This question serves to form stakeholder groups that are addressed in the SLCA. Relationships between effects and stakeholders may extend and overlap, since some effects can have impacts on several stakeholder groups simultaneously. Especially impacts on workers or local communities are strongly linked to the (national) society too (e.g., occupational disease affects a worker's well-being and, at the same time, the health system and, in turn, society will also be 
Table 1 Definition of terms used in SLCA

\begin{tabular}{|c|c|}
\hline Term and hierarchy & Definitions \\
\hline $\begin{array}{l}\text { Social aspects } \\
\text { TOPICS }\end{array}$ & $\begin{array}{l}\text { Describes the subject to be measured [17]; also defined as social performance [18]; } \\
\text { anything related to human well-being; any number of general topics (objectives, } \\
\text { social issues, opportunities, indicators, indices, impact categories) [19] - descrip- } \\
\text { tion of the general topic. }\end{array}$ \\
\hline $\begin{array}{l}\text { Social effects } \\
\text { EFFECTS }\end{array}$ & $\begin{array}{l}\text { A social phenomenon's causes induced by changes; social effects can cause impacts } \\
\text { [20] - social effects are related to social aspects }\end{array}$ \\
\hline $\begin{array}{l}\text { Social impacts } \\
\text { IMPACT }\end{array}$ & $\begin{array}{l}\text { Describes consequences, caused by changes, influencing peoples' lives directly [20]; } \\
\text { "are everything that affect people" stated by Vanclay et al. [21] - therefore, } \\
\text { impacts are caused by effects }\end{array}$ \\
\hline $\begin{array}{l}\text { Social (impact) ategory } \\
\text { STRUCTURE } \\
\text { IN SLCA }\end{array}$ & $\begin{array}{l}\text { Describes a broad area of influence; each category is defined by a number of aspects } \\
\text { [17]; referred to as social index in Siebert et al. [19]; every index characterized by } \\
\text { one or several indicators; describes unknown cause-effect-relationships [19]—used } \\
\text { for a structured description of the impacts }\end{array}$ \\
\hline $\begin{array}{l}\text { Social (impact) subcat- } \\
\text { egory } \\
\text { SUB-STRUCTURE } \\
\text { IN SLCA }\end{array}$ & $\begin{array}{l}\text { Describes a more refined classification of the term category; subcategories are } \\
\text { understood as a compilation and combination of social topics, issues, aspects, and } \\
\text { also effects, which are used to be measured and validated by one or several } \\
\text { indicators. The UNEP/SETAC Guidelines [8] define the term subcategory as "so- } \\
\text { cial and socioeconomic issues of concerns"- used as a sub-structure of categories }\end{array}$ \\
\hline $\begin{array}{l}\text { Social indicator } \\
\text { MEASUREMENT IN } \\
\text { SLCA }\end{array}$ & $\begin{array}{l}\text { No overall accepted definition [22]; a sign, symptom, or signal that shows something; } \\
\text { gives information if something is existing or true [22, 23]; measures an aspect, one } \\
\text { aspect can be measured by several indicators [17]—used to measure impact } \\
\text { (sub-)categories in SLCA }\end{array}$ \\
\hline
\end{tabular}

affected to some extent). One possibility is to differentiate between direct and indirect effects. Identifying the stakeholder groups concerned needs to be a priority, but as is the case for indicator selection, there are no clear standards for identifying stakeholders.

The choice of indicators can restrict the social topics addressed in an SLCA study. The crucial step of indicator selection thus already defines the results that can be drawn from the study. It is essential to pay close attention, to set the focus on those social aspects, that are of particular relevance for the stakeholders concerned. There is a vast number of prevalent indicators but a lack of generalized and standardized indicators reflecting social performance clearly [15]. Due to the high numbers of indicators used in SLCA, the indicator selection process becomes a bottleneck, not the availability of indicators [28]. In order to address those social aspects that are particularly critical and relevant, consulting stakeholders and experts consultation is of high priority [29-32], as it is recommended by the UNEP/SETAC Guidelines [8]. A review of SLCA studies by Martin et al. [16] shows, that stakeholder input is used in most of the studies to consider the relevant social indicators. Multi-criteria-decision approaches can be used to weight selected indicators via experts' scores (using a Likert scaling) [20]. This approach has been broadly utilized for the past 15 years [33]. Attention must be paid to what kind of stakeholders are engaged in the study, because perceptions regarding the importance of impacts and indicators will vary since such perceptions are subjective [16]. Stakeholders directly affected can give a thorough insight into their risks and needs but representatives should reflect the risks and needs of a larger number of individuals or of entire stakeholder groups. Additionally, public decision-makers are of core interest, since they can actively influence the effects through regulatory measures [29]. It is valuable to pay close attention to the indicator selection process to ensure efficient data collection, which will result in an effective assessment [34]. The cause and effect chains in SLCA are not as obvious as in conventional LCA [19], which makes the choice of indicators even more complex. In addition to stakeholder-specific social aspects, SLCA has to consider regional and context-specific social aspects [19] as well. To choose relevant social aspects on a global, regional, national, and sub-national level was also suggested by Bracco et al. [35]. This challenges the standardization of indicators, which takes a high priority in the development of the method $[15,36]$ and makes it necessary to develop indicators on sectoral and regional levels.

The aim of this paper is to provide a guiding framework for the identification of social and socioeconomic aspects and indicators relevant for the SLCA of bio-based value chains, produced from SRC dendromass, especially in Eastern Europe. To tackle the under-investigated social dimension, we developed a framework built upon the work of Siebert et al. [19] and applied it to a case study demonstrating its feasibility. Thereby, we propose a set of social aspects and corresponding indicators to be used in SLCA studies. This should help to save time and resources in later studies on the methodological choice on the one hand and through the availability of a final set of indicators for comparable studies on the 
other hand. Therefore, three different steps for the selection of social impact categories and indicators are proposed and tested. These steps including a literature review, stakeholder consultation, and social risk mapping with a specialized tool, to answer the following research questions:

- Which SLCA guidelines and sustainability standards are relevant for bio-based value chains from Short Rotation Coppice dendromass?

- Which social aspects and indicators are relevant for the socioeconomic assessment of bio-based products from Short Rotation Coppice dendromass?

- Which social aspects and indicators are prioritized by stakeholders to be included into the SLCA of bio-based products from Slovakian Short Rotation Coppice dendromass?

\section{Materials and Methods}

Our study is built upon three different steps for the identification of relevant social aspects and indicators in SLCA. These three steps are applied and tested on a case study as described in the following.

\section{Description of the Case Study}

The case study carried out investigations of the social aspects of relevance, caused by SRC-based dendromass production in Eastern Slovakia. A new value chain is being established in a demonstration project with the aim of regional dendromass production in Slovakia, feeding into the cascading use for several bio-based materials. For this purpose, fast-growing poplars are cultivated in Short Rotation Coppice (SRC) on marginal agricultural land, harvested in short intervals with a high level of mechanization. From a legal point of view, the planting of trees on agricultural land in Slovakia is regulated by Act no. 220/2004 Coll., on the Protection and Use of Agricultural Land ("Soil Protection Act") [37]. Land that is classified with the quality from 5 to 9 in the code of eco-land evaluation unit ("ELEU") or contaminated land can be cultivated with SRC for a maximum of 20 years [37]. Poplars from $\mathrm{SRC}$ as a source for dendromass are more widely established in the field of energy production but also represent one way to gain a natural resource in the immediate vicinity for processing industries.

The Slovakian Ministry of Agriculture and Rural Development has been leading the development of a national bioeconomy strategy since 2018. To date, Slovakia is already part of the Central-Eastern European Initiative BIOEAST, an initiative for knowledge-based agriculture, aquaculture, and forestry in the bioeconomy, to foster a sustainable bioeconomy [38]. Employment and turnover are considered as a proxy for the socioeconomic relevance of the bioeconomy sector. In Slovakia, 174,000 people were employed in the bioeconomy sector in the year 2015 [39]. The turnover of the Slovak bioeconomy in 2015 was at 11 Billion $€$, with the second highest share in the country being attributed to the agricultural sector [39].

\section{Proposed Methodology for Indicator Selection}

A multi-methodological approach was chosen to identify and prioritize relevant indicators. The basis of provided indicators is found in the "Methodological Sheets for Subcategories in SLCA to by Benoit-Norris et al. [40], a supplement to the UNEP/SETAC Guidelines that also offers a vast number of indicators. In accordance with Siebert et al. [19], the selection is based on screening social aspects and impact categories in SLCA guidelines, sustainability standards on a global, national, and sector-specific level and a literature review on articles of SLCA studies in a related context (bio-based value chains). The following subchapters describe the three steps of the indicator-selection approach depicted in Fig. 1. The different steps intend to provide an extensive picture of potential social aspects, going beyond minimal compliance to assess additional and complementary social impacts, as required by Benoît et al. [8]. The combination of the three steps results in an initial hot spotting, including the main social implications occurring along the value chain under investigation.

To the author's knowledge, there are three common practices for identifying impact categories and indicators in SLCA, summarized in the following three points:

1. Indicator screening: a literature review is carried out to some extent in nearly every study screened so far. The consultation of literature can be seen as the basis for further investigations. Especially a comparable research topic allows to include social aspects from earlier studies [41]. The screening of indicators can include guidelines and instructions for SLCA, sustainability standards on global, national, or sector-specific level [19], and scientific publications in the respective field of interest, including SLCA case studies.

2. Stakeholder engagement: a participatory approach is proposed by several authors (e.g., Benoît et al. [8] or Mathe [29]). Prior to indicator-selection by stakeholders, it is of importance to identify the respective stakeholders.

3. Risk mapping: the consultancy NewEarth B established the Social Hotspots Database (SHDB) and provides purchasable licenses for using the "SHDB Risk Mapping Tool" [42]. This database was chosen because the webbased tool enables the researcher to identify country- and sector-specific hotspots in a time-saving manner. But 
Impact Categories and Indicators Selection Process

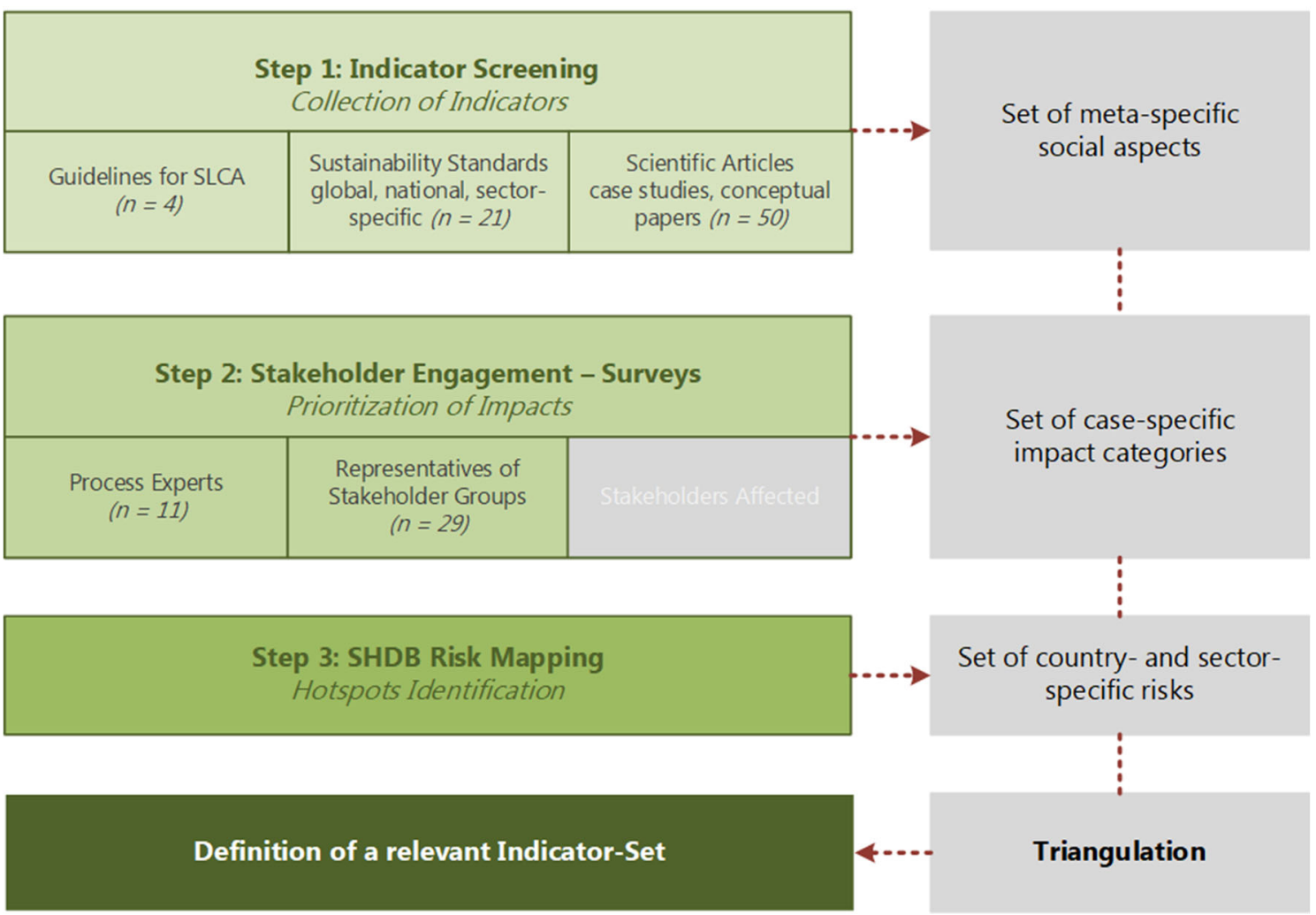

Fig. 1 Procedure of indicator selection, fragmentarily adopted from Siebert [19], supplemented with several crucial steps like diversification in stakeholder engagement, risk mapping, and triangulation (own figure)

there are also other databases available for SLCA, such as PSILCA or solca by GreenDelta.

Step 1: Indicator Screening (Literature Review) An indicator screening was carried out reviewing guidelines for SLCA, sustainability standards, and scientific peer-reviewed articles. To the author's knowledge, four different guidelines are used as the basis for implementing an SLCA, which are (1) the UNEP/SETAC Guidelines for Social Life Cycle Assessment of Products [8], published in 2009; (2) the ISO 14040: International Standard for Environmental management-Life cycle assessment-Principles and Framework [43, 44], published in 2006; (3) the Product Social Impact Assessment (PSIA)-Methodology and Handbook (also referred to as: Pré Sustainability Assessment) [9, 45], published in 2018 as well as (4) the SEEbalance ${ }^{\circledR}$ method [46], published in 2004. The consultation of SLCA literature has shown that the UNEP/ SETAC Guidelines are frequently referred to in literature. Less attention is paid to the Product Social Impact Assessment (PSIA) and the SEEbalance $\odot$, which focus on socio-eco-efficiency analysis. Although ISO 14040 does not offer specific guidance for SLCA, it does provide the basis for LCA and should therefore serve as a basis for SLCA also. Therefore, it is also included in the list of guidelines for SLCA. Information on relevant sustainability standards was gathered by snowballing in reviewed publications and online, mainly using the Google search engine and screening references of related publications. In accordance with Siebert et al. [19] and Bracco et al. [35], the selection of relevant sustainability standards is based on a global, national, and sectorspecific level. Obtaining any information about social and socioeconomic impact categories or indicators in sustainability standards at the national level in Slovakia is particularly challenging. However, this work focuses on standards relevant to the bio-based and agricultural sector in general and with a specific focus on Slovakia.

Furthermore, a systematic literature review was carried out. The common search engines Scopus (SCO), Web of Science (WOS), and Cambridge Scientific Abstracts (CSA) were consulted. In accordance with terms used in specific literature, the following different terms for SLCA, like "Social Life Cycle Assessment," "SLCA," "S-LCA," "Social LCA," and "SOLCA" were used in combination with "Indicator*" and 
"Impact Categor*" for general results on indicators in SLCA, but also in combination with "Short Rotation Coppice," "Short Rotation Plantation," "SRC," and "SRP" to check for more specific information. Additionally, for SLCA studies on the final bio-based products of concern, terms like "lightweight fibre board," "eco-fungi," "moulded fibre," "WPC," or "Wood Plastic Composit*" (non-exhaustive listing) were included. Due to the focus on SLCA in this study, no other sustainability assessments were included in the review. This search strategy resulted in 268 (SCO), 630 (CSA), and 193 (WOS) hits respectively for the general studies on impact categories and indicators. The specific search terms on SRC as well as the terms lightweight fibre boards, eco-fungicidal moulded fibre parts, and WPC, which represent the final biobased products under study, led to a much smaller number of results. Overall, these terms yielded 4 (SCO), 313 (CSA), and 3 (WOS) hits respectively for all terms summarized. In the following, the abstracts of all studies were screened, and the selection of relevant articles was based on addressing the listed thematic areas, implementation of an SLCA in the respective field of interest as well as methodological approaches respective to social aspects and indicators. Grey literature (conference proceedings, dissertations) and studies on a field not comparable (e.g., aquaculture, greenhouse legumes growing, livestock production) were excluded. Finally, 50 studies have been identified as suitable for the content analysis, shown in Table 2, where the reference is assigned to the relevant sector and geographical location of the study. The content analysis was based on the categorization of social impact (sub-) categories, indicators, stakeholders addressed, information on the indicator selection process, and number of indicators stated as well as general information on the scope of the study and the production system. The qualitative data analysis of the publications was done using the software Atlas.ti, to establish an inductive category system. This preliminary work was necessary to aggregate the impacts and indicators collected into relevant social aspects addressed in the different studies. Summarizing the different parts of literature screening from Step 1, a set of indicators on a meta-level was obtained.

Step 2: Stakeholder Engagement To obtain a more comprehensive picture, and to avoid a shift towards specific interests of engaged individuals or groups, a multi-level stakeholder consultation process was implemented. Therefore, subsequent to the literature screening, an online survey was conducted to prioritize the social aspects according to stakeholders' and experts' input. A two-step approach was implemented, covering the opinion of process experts, which includes individuals directly involved in the case studies project and representatives of the stakeholder groups involved. The questionnaire was built up based on the work of Karlewski [88], which had the advantage that this survey method has already been tested. Their survey was also carried out to grasp the importance of social aspects for an SLCA in the context of a complex international value chain (automobile). The indirect question method, supplemented with examples should help to better understand the social aspects proposed. For that reasons, this method seemed suitable for our application also. The Stakeholders' perspective was gauged using a six-point Likert scale ranging from $1=$ "very important" to $6=$ "not important at all", to determine the perception on the significance of the social aspects given. This approach is known to weight the sustainability criteria through stakeholders' preferences, which makes the decision on social indicators more relevant on a local level $[50,89]$. A regionally dispersed value chain, as is often found in the bioeconomy, makes it necessary to integrate stakeholders from different regions into the survey [90].

Two surveys are divided, engaging (1) process experts, having detailed knowledge about the production processes going on and (2) stakeholders' representatives, representing the stakeholder groups concerned. Due to the very specialized group of participants, the survey had to be conducted on a very small scale. An online survey for that kind of stakeholder engagement is a good way to capture the opinions of people from diverse backgrounds. As the target group for the surveys is not a homogeneous group, but rather people with different professional backgrounds, from different countries and language backgrounds, it would have been challenging to involve the stakeholders in the form of face-to-face contact, such as in the course of a workshop. Furthermore, plans to conduct at least parts of the survey within a workshop in the spring of 2020 were disrupted by the COVID-19 pandemic. Two main tasks were given in the course of the survey. On the one hand, the participants were asked to rank the four common stakeholder groups according to their importance to be included in the SLCA. Under an "others" category, participants had the opportunity to name an additional stakeholder group. On the other hand, the participants were asked to rate the priority of including specific social aspects, regarding the stakeholder groups workers (11 aspects), local communities (11 aspects), society (5 aspects), and value chain actors (4 aspects), into the SLCA study. The social aspects to be assessed include all subcategories proposed by the UNEP/SETAC Guidelines. In addition, for the stakeholder group "workers," the aspects safe working conditions, training and work-life-balance were added, and for the stakeholder group "local community," the aspects regional value creation and contribution to economic development were added. The aspect respect of indigenous rights was used in a modified form to also include local communities' rights. With the option "others" the possibility was given to add additional aspects.

The process experts' survey was carried out prior to the survey of stakeholder's representatives. This approach allowed an intensive testing of the survey. The process experts 
Table 2 Studies on SLCA providing social aspects and/or indicators for the assessment of agricultural and bio-based production systems as well as conceptual or methodological papers on SLCA indicators.

\begin{tabular}{|c|c|c|}
\hline $\mathrm{Nb}$. & Source & Geographical scope \\
\hline \multicolumn{3}{|c|}{ Type of product/field of application: agriculture } \\
\hline 1 & Franze and Ciroth 2011 [47] & Ecuador, Netherlands \\
\hline 2 & De Luca et al. 2014 [48] & Italy \\
\hline 3 & Vavra et al. 2014 [49] & Czech Republic \\
\hline 4 & De Luca et al. 2015 [50] & Italy \\
\hline 5 & Tecco et al. 2016 [51] & Italy \\
\hline 6 & Arcese et al. 2017 [52] & Italy \\
\hline 7 & Sawaengsak and Gheewala 2017 [53] & Thailand \\
\hline 8 & Lim and Biswas 2018 [54] & Malaysia \\
\hline 9 & De Luca et al. 2018 [55] & Italy \\
\hline 10 & Prasara-A and Gheewala 2018 [56] & Thailand \\
\hline 11 & Petti et al. 2018 [57] & Italy \\
\hline 12 & De Luca et al. 2018 [58] & Italy \\
\hline 13 & Prasara-A and Gheewala 2019 [59] & Thailand \\
\hline 14 & Iofrida et al. 2019 [60] & Italy \\
\hline 15 & Du et al. 2019 [61] & Brazil \\
\hline 16 & Du et al. 2019 [62] & Brazil \\
\hline 17 & Muhammad et al. 2019 [63] & Malaysia \\
\hline 18 & Martucci et al. 2019 [64] & Italy \\
\hline 19 & Sawaengsak et al. $2019[65]^{*}$ & Thailand \\
\hline \multicolumn{3}{|c|}{ Type of product/field of application: bio-based energy, bio-fuel } \\
\hline 20 & Lehmann et al. 2011 [66] & Developing countries \\
\hline 36 & Valente et al. 2011 [67] & Norway, USA \\
\hline 21 & Macombe et al. 2013 [20] & Finland \\
\hline 22 & Henke and Theuvsen 2013 [68] & Germany \\
\hline 23 & Manik et al. 2013 [69] & Indonesia \\
\hline 24 & Ekener-Petersen et al. 2014 [70] & Brazil, USA, France, Lithuania \\
\hline 25 & Weldegiorgis and Franks 2014 [71] & Australia \\
\hline 26 & Pashaei Kamali et al. 2014 [72] & Latin America, European Union \\
\hline 27 & Dewulf et al. 2015 [73] & - \\
\hline 28 & Dos Santos and Brandi 2015 [74] & Argentina, Brazil, China, USA, France \\
\hline 29 & Ren et al. 2015 [75] & China \\
\hline 30 & Sanchez Ramirez et al. 2016 [76] & Brazil \\
\hline 37 & Ekener et al. 2016 [25] & General \\
\hline 31 & Contreras-Lisperguer et al. 2018 [77] & Jamaica \\
\hline 32 & Sajid and Lynch 2018 [78] & Canada \\
\hline 33 & Rafiaani et al. 2018 [33] & General \\
\hline 34 & Martin et al. 2018 [16] & Sweden \\
\hline 35 & Souza et al. 2018 [79] & Brazil \\
\hline 38 & Collotta et al. 2019 [80] & General \\
\hline \multicolumn{3}{|c|}{ Type of product/field of application: bio-based products } \\
\hline 39 & Agyekum et al. 2017 [81] & Ghana \\
\hline 40 & Falcone and Imbert 2018 [32] & General \\
\hline 41 & Spierling et al. 2018 [5] & General \\
\hline 42 & Blanc et al. 2019 [82] & General \\
\hline 43 & Prasara-A et al. 2019 [18] & Thailand \\
\hline \multicolumn{3}{|c|}{ Type of product/field of application: bioeconomy } \\
\hline 44 & Siebert et al. 2018 [19] & Germany \\
\hline
\end{tabular}


Table 2 (continued)

\begin{tabular}{lll}
\hline $\mathrm{Nb.}$ & Source & Geographical scope \\
\hline 45 & Falcone et al. 2019 [14] & General \\
$\begin{array}{l}\text { Type of product/field of application: } \\
46\end{array}$ & Giorefinery \\
Type of product/field of application: & methodological or conceptual papers \\
47 & Kolotzek et al. 2018 [84] & General \\
48 & Sureau et al. 2018 [85] & General \\
49 & Liu and Aswara 2019 [86] & General \\
50 & Rafiaani et al. 2019 [87] & General \\
\hline
\end{tabular}

*Belongs equally to the field of application: bio-based energy

selected for the survey are directly involved in the establishment of the production processes or the $R \& D$ on the respective value chain and, thus, could be contacted personally. Since they should have an exact picture of which processes are occurring along the value chain, the process experts' survey was carried out separately. Therefore, in this survey, the opportunity was given to assess the importance of the social aspects in an SLCA for all stakeholder groups. After this survey did not show any problems, and no feedback about poor comprehensibility was received, the survey was distributed to a range of representatives of the stakeholder groups concerned. The target group for the second survey included employee and worker's representatives (e.g., farmers' and workers' associations), mayors of different villages and other representatives of local communities, NGOs on respective issues, as well as business partners, representing value chain actors. A total of around 165 people of interest were found through online research and conversations with process experts. These people were contacted in the spring of 2020 by e-mail with a short explanation of the projects' goal and were asked to participate on a voluntary basis. After 3 weeks, an email with thanks for the participation and reminding those who had not yet participated was sent out. This approach made it possible to find out the stakeholders' views and opinions on the social aspects in an anonymous way. Every survey provided a combination of prioritizing given social aspects and adding additional topics for every stakeholder group, as well as adding additional stakeholder groups.

Eleven completed surveys from process experts', including answers from all addressed organizations, and 29 completed surveys out of 78 in total from the stakeholders' representatives could be included in the statistics. The respondents were asked which stakeholder group they can represent, where 12 answers were assigned to "workers," 6 to "local community," 4 to "society," 5 to "other value chain actors," and 9 to "other," an additional stakeholder group. For the analysis, Microsoft Excel was used to describe the response frequencies. The mean values of the Likert scales were used to obtain the level of agreement on the importance of the social aspects and therefore, a tendency for prioritization.

Step 3: Risk Mapping In the third step, the Social Hotspots Database Risk Mapping Tool was consulted to consider a hotspots mapping on a country- and sector-specific basis. The web-based tool provides the opportunity to include 57 sectors and 191 countries [91]. Suitable for the present study, the sectors "crops" and "wood products" were selected for the country Slovakia. The integrated database is built on international statistics and estimates a potential risk exposure from the level "low," "medium," "high" to "very high". The results were processed in Microsoft Excel.

\section{Triangulation}

After steps 1-3 had been carried out, the results of these parts could be merged by triangulation. The principle of triangulation (originally mentioned by Webb et al. [92]), was applied to improve the reliability [93] and the confidence [94] of the single indicator-sets. A comparison by several applied methods or different data sets allowed us to cross-check the results [94] and highlight different perspectives on the object under investigation [93]. In this context, method-, data-, theory-, and investigator-triangulation were differentiated [93]. In our study, a mix of method- and data-triangulation was applied, which was intended to glean more knowledge about the main social aspects for SLCA. Data triangulation requires the integration of different data sources that should investigate different perspectives in time, places, and people on the same phenomenon [93]. The combination of methods includes "within-method-triangulation" (e.g., different scales in one questionnaire) and "between-method-triangulation" (the use of different methods), to overcome the limitations of one single method [93]. However, the focus should be on a highly critical selection process and on checking the appropriateness of the chosen methods [93]. For our purpose, the results were compared in a table to visualize similarities and 
contradictions. By complementing the various methods and data sets, the results will be aggregated more densely, deriving higher redundancy, validity, frequency, appropriateness, and reliability.

\section{Results}

The aim of this publication is to identify the most relevant social and socioeconomic aspects and indicators for the SLCA of bio-based value chains, produced from SRC dendromass, especially in Eastern Europe. These so-called "hotspots" are of particular social interest, as these aspects are presumed to have a particularly high potential for conflicts. Therefore, the subsequent presented social and socioeconomic hotspots are of particular relevance to be included into a detailed SLCA. It is recommended to consider these aspects in detail for the respective foreground system in an SLCA study and to assess potential implications in the foreground system as far as possible with primary data.

\section{Literature Review}

Guidelines for SLCA: at the very beginning of the literature review, it makes sense to consult guidelines for the implementation of an SLCA. Four guidelines have been identified that contain a number of social and socioeconomic aspects as well as indicators and provide the methodological framework for carrying out an SLCA. However, it is not possible to conclude on their relevance for any particular application. Table 3 gives insight into the impact categories of the guidelines with their respective stakeholder groups addressed. All guidelines, except the ISO 14040 norm, which does not provide special information about socioeconomic impact categories, but gives the basic methodological framework of life cycle assessment, include the stakeholder groups workers or employees, consumers, users, or customers, as well as local community. The proposed impact categories for workers and employees deal mainly with working conditions (e.g., fair salary, child labor, and discrimination) as well as health and safety issues. Health and safety for consumers, users or customers are also included in all three guidelines. Benoît et al. [8] and Goedkoop et al. [45] propose health and safety impact categories also for the stakeholder group local community, whereas Schmidt et al. [46] focuses mainly on the issues of job provision for this group. Additionally, less common stakeholder groups are proposed by Goedkoop et al. [45], including small-scale entrepreneurs as a stakeholder group of their own. Goedkoop et al. [9] define this group as an independent person, earning their living in family structures by small-scale production of food and non-food products, characterized by limited access to resources. The main issues that may affect this group coincide mostly with the issues of the more general groups workers and local communities. In contrast, Schmidt et al. [46] include the stakeholder groups' future generations and international community. The social issues concerned with these groups, can be widely associated with the issues concerning the stakeholder group society generally.

Sustainability Standards A range of social aspects could be drawn from screening sustainability standards on a global, national, and sectoral level. It can be observed that social aspects derived from sustainability standards have a strong focus on workers' needs (compare Table 4). Almost all standards chosen, except "Greener Slovakia" and the "National Bioeast Hub," include social aspects that can be assigned to the stakeholder group "workers." In addition to the stakeholder group workers, social aspects concerning the "local community" or "society" are also frequently addressed. Social aspects regarding "value chain actors" and "consumers" could only be found in GRI standards and the SAFA standard. For the current study, it is especially interesting, that the ILO standards provide an extra convention on plantations (No. 110). Furthermore, the results show that the sector-specific and national sustainability standards lay a particular focus on food security as well as on safety, creation of jobs and rural development. Due to limited space, the table with all social aspects drawn from the sustainability standards is provided in the supplementary material. Table 4 indicates the stakeholder groups that are addressed by the social aspects mentioned in the respective sustainability standard. An estimation of the importance or significance of the respective aspects drawn from the standards is complex. It is challenging to determine the background to the work on which the standards are based and to judge their comprehensiveness. Due to a lack of search criteria, a complete picture of the selected sustainability standards cannot be guaranteed. Global standards are sector and cross-country standards, established by recognized organizations. National standards are based on a general level, as are the global standards. In this study, Slovak standards were sought to address the country-specific social sustainability aspects. The sectoral standards, on the other hand, may again be relevant at the international or EU level. In the present study, sustainability standards for the agricultural sector, and specifically for the bio-based industry, are included. The findings show that many of the social aspects are overlapping, since national or sectoral standards often adopt aspects from global standards.

Scientific Publications (Case Studies with Related Focus, Conceptual Papers, etc.) In our literature review on SLCA, case studies with a related research focus and papers on conceptual SLCA or sustainability indicators have been included. Out of the 50 analyzed studies, only one study is dealing directly with dendromass production in SRC; however, their focus of study was production feeding into energy generation 
Table 3 Social and socioeconomic impact categories for SLCA derived from several guidelines

\begin{tabular}{|c|c|c|c|c|}
\hline $\begin{array}{l}\text { Consulted Guidelines for } \\
\text { the establishment of a } \\
\text { SLCA }\end{array}$ & & $\begin{array}{l}\text { UNEP/SETAC } \\
\text { Guidelines }\end{array}$ & 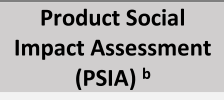 & SEEbalance ${ }^{\circledR c}$ \\
\hline $\begin{array}{c}\text { Stakeholder group } \\
\text { concerned }\end{array}$ & $\begin{array}{l}\text { Social and socio-economic impact categories } \\
\text { (subcategories) for SLCA }\end{array}$ & & & \\
\hline \multirow{13}{*}{ "workers"; "employees" } & freedom of association and collective bargaining & - & - & \\
\hline & child labor & • & $\bullet$ & \\
\hline & fair salary; remuneration & $\bullet$ & $\bullet$ & $\bullet$ \\
\hline & working hours & - & & \\
\hline & forced labor & - & • & \\
\hline & equal opportunities/ discrimination & $\bullet$ & $\bullet$ & \\
\hline & health and safety & • & $\bullet$ & \\
\hline & social benefits /social security / company benefits & - & & - \\
\hline & work-life balance & & $\bullet$ & \\
\hline & (fatal) occupational and commuting accidents & & & $\bullet$ \\
\hline & occupational diseases & & & • \\
\hline & professional training & & & $\bullet$ \\
\hline & strikes and lockouts & & & $\bullet$ \\
\hline \multirow{12}{*}{$\begin{array}{l}\text { "consumers"; "users"; } \\
\text { "customers" }\end{array}$} & health \& safety & - & $\bullet$ & - \\
\hline & feedback mechanism & - & & \\
\hline & consumer privacy & - & - & \\
\hline & transparency & - & & \\
\hline & End-of-life responsibility & $\bullet$ & & \\
\hline & product safety & & & \\
\hline & responsible communication & & - & \\
\hline & inclusiveness & & $\bullet$ & \\
\hline & effectiveness and comfort & & $\bullet$ & \\
\hline & extra benefits that enhance customer satisfaction & & & $\bullet$ \\
\hline & completeness and quality of product information & & & - \\
\hline & consumer labels & & & - \\
\hline \multirow{7}{*}{$\begin{array}{l}\text { "local community"; } \\
\text { (* including society) }\end{array}$} & access to material/tangible resources & - & - & \\
\hline & access to immaterial resources & • & & \\
\hline & delocalization and migration & $\bullet$ & & \\
\hline & cultural heritage & • & & \\
\hline & safe $\&$ healthy living conditions & • & - & \\
\hline & respect of indigenous rights & $\bullet$ & & \\
\hline & community engagement & $\bullet$ & - & \\
\hline
\end{tabular}

rather than the production of bio-based products. No limits regarding the time of publication were set for the search process. The results showed publications starting in 2011, which highlights that SLCA is still a relatively young field in science. An increasing trend in publications can be identified in 2018, which is in line with publications on SLCA in general (compare Kühnen and Hahn [15] or Spierling et al. [5]). The geographical distribution of the regions addressed shows that, above all countries, of the European Union (18 mentions) with a strong focus on Italy, South-East Asian and South American countries are included in the studies (compare Table 2). Studies for the Eastern European region or Slovakia are missing, except one study for the Czech Republic. This shows that SLCA is still underrepresented in this geographical focus. Most articles found were published in the International Journal of Life Cycle Assessment (14 publications), closely followed by the Journal of Cleaner Production (13 publications). This is followed by the journal Sustainability with just four publications remaining. Interestingly, no article regarding the respective topic was published in the journal BioEnergy Research.
The analysis of the selected publications focused on the social aspects, more precisely on the social and socioeconomic impact (sub-)categories or the respective indicators. As already discussed in the introduction, the definition of the terms is very controversial, which made the coding of the impact categories and indicators challenging. In order to structure this process, the subcategories of the UNEP/SETAC Guidelines were used as a basis and were supplemented by the impact categories mentioned in the articles. Following this procedure, 118 impact categories were identified. The impact categories addressed show a clear trend towards worker's health and safety aspects (compare Fig. 2). A strong focus on the stakeholder group "workers" as well as on investigations in the area of health and safety is in line with the findings of other authors. This can be explained simply with respect to the undeniable importance of the topic on the one hand, but it can also be justified by the availability of clearly defined and measurable indicators in this area and should therefore not automatically be seen as the only and most important social aspect in SLCA. It is striking that most of the impact categories assigned refer to the subcategories mentioned in the UNEP/ 
Table 3 (continued)

\begin{tabular}{|c|c|c|c|}
\hline & local employment & $\bullet$ & $\bullet(*, 1)$ \\
\hline & secure living conditions & - & - $(*, 2,3)$ \\
\hline & $\begin{array}{l}\text { violation of ethical norms due to product use or } \\
\text { advertisement }\end{array}$ & & $\bullet(*)$ \\
\hline & potential misuse of products & & $\bullet(*)$ \\
\hline \multirow{5}{*}{ "society" } & Public commitments to sustainability issues & - & \\
\hline & contribution to economic development & - & \\
\hline & prevention \& mitigation of armed conflicts & - & \\
\hline & technology development & - & \\
\hline & corruption & - & \\
\hline \multirow{8}{*}{$\begin{array}{l}\text { "value chain actors" } \\
\text { (not including consumers) }\end{array}$} & Fair competition & - & \\
\hline & promoting social responsibility & - & \\
\hline & supplier relationships & - & \\
\hline & respect of intellectual property rights & $\bullet$ & \\
\hline & freedom of association & & - \\
\hline & discrimination & & - \\
\hline & forced labor & & $\bullet$ \\
\hline & child labor & & - \\
\hline \multirow{7}{*}{$\begin{array}{l}\text { "small-scale } \\
\text { entrepreneurs" }\end{array}$} & meeting basic needs & - & \\
\hline & access to services and inputs & $\bullet$ & \\
\hline & women's empowerment & $\bullet$ & \\
\hline & child labor & - & \\
\hline & health and safety & - & \\
\hline & land rights & - & \\
\hline & fair trading relationships & $\bullet$ & \\
\hline \multirow{4}{*}{ "future generations" } & number of trainees & & - \\
\hline & expenditure for $R \& D$ & & - \\
\hline & capital investment & & • \\
\hline & company expenditures for social security & & - \\
\hline \multirow{3}{*}{ "international community” } & imports from developing countries & & - \\
\hline & sum of import duties and export subsidies & & - \\
\hline & fair trade labels & & - \\
\hline
\end{tabular}

${ }^{1}$ Number of employees; number of unskilled workers; number of female managers; number of disabled employees; number of part-time workers; ${ }^{2}$ company expenditures for family support; benefits for disadvantaged people; ${ }^{3}$ potential of intensification of social and political conflicts

${ }^{a}$ UNEP/SETAC Guidelines for Social Life Cycle Assessment of Products [8]; ${ }^{b}$ Product Social Impact Assessment (PSIA)-Methodology and Handbook (also referred to as: Pré Sustainability Assessment) $[9,45]$; ${ }^{\mathrm{c}} \mathrm{SEEb} a \mathrm{ance} 囚[46]$

SETAC Guidelines. The 33 most frequently used impact categories completely cover the 31 subcategories of the guidelines; only the impact categories "food security" and "working conditions," as a more general term for impacts on the stakeholder group "workers," fall within this range. These impact categories are within the red box in Fig. 2. Additionally, the assignment of the impact categories according to the respective stakeholder group is illustrated in Fig. 2. The reviewed articles show outnumbered impact categories or indicators for the stakeholder group "workers;" $42 \%$ of all impact categories are related to this stakeholder group. This reflects the overall situation in SLCA studies, where, in general, a high number of social aspects and indicators is relevant, but a strong focus is placed on workers' issues [15]. The "local community" is addressed with $29 \%$, "society" with $15 \%$, "consumers" with $7 \%$ and "value chain actors" with $6 \%$ of all impact categories. This shows that the stakeholder groups "consumers" and "value chain actors" are underrepresented with impact categories in SLCA. Only $1 \%$ of the impact categories found could not be clearly assigned to these stakeholder groups.
While it is important to note that the subcategories of the UNEP/SETAC Guidelines were considered as the basis for the coding, it also shows that they provide a rather complete picture of commonly used impact categories or subcategories in their meaning. Nevertheless, this does not mean that additional social aspects are not relevant to the study. Especially, indicators taking the regional or sectoral context into account are of major relevance in SLCA studies [19, 96, 97]. In order to get a grasp of the amount of different indicators or impact categories, their occurrences per article were assessed. This resulted in an average of 19.5 indicators or impact categories per article. While some articles deal with only one single indicator or social aspect, for example, Blanc et al. [82], other articles deal with more than 50 indicators at once (e.g., Sanchez Ramirez and Petti [76] or Martucci et al. [64]). A majority of the studies reviewed conduct stakeholder opinions for the selection of indicators (e.g., Manik et al. [69], De Luca et al. [50], Sawaengsak et al. [65], or Rafiaani et al. [87]). Only a few studies, such as Arcese et al. [52], are built solely on indicators from a literature review or on the impact categories listed in the UNEP/SETAC Guidelines (see also Franze and Ciroth [47] or Lehmann et al. 
Table 4 Sustainability standards (global, national, and sector-specific) included in the indicator screening and the stakeholder groups addressed by their social and socioeconomic aspects (the whole list of addressed social and socioeconomic aspects could be found in the supplementary material)

\begin{tabular}{|c|c|c|c|c|c|c|}
\hline \multicolumn{2}{|c|}{ Consulted Guidelines for the establishment of an SLCA } & \multicolumn{5}{|c|}{ Stakeholder Group } \\
\hline Level & Reference (sustainability standard) & Workers & Local Community & Society & Consumer & $\begin{array}{l}\text { Value Chain } \\
\text { Actors }\end{array}$ \\
\hline \multirow{6}{*}{ Global } & ILO standards - International Labor Organization & - & & & & \\
\hline & $\begin{array}{l}\text { SDGs (Sustainable Development Goals) - United } \\
\text { Nations }\end{array}$ & $\bullet$ & $\bullet$ & $\bullet$ & & \\
\hline & $\begin{array}{l}\text { FSC - International Generic Indicators (also FSC and } \\
\text { Plantations) }\end{array}$ & $\bullet$ & $\bullet$ & $\bullet$ & & \\
\hline & $\begin{array}{c}\text { ISO } 26000 \\
\text { (adopted by Slovakia as national standard) - by UN } \\
\text { Global Compact Principles }\end{array}$ & $\bullet$ & • & • & & \\
\hline & $\begin{array}{l}\text { GRI Standards - Global Sustainability Standards Board } \\
\text { (GSSB) }\end{array}$ & $\bullet$ & $\bullet$ & $\bullet$ & $\bullet$ & $\bullet$ \\
\hline & SA $8000^{\star}: 2014-$ Social Accountability International & $\bullet$ & & & & \\
\hline \multirow{4}{*}{ National } & Agenda 2030 - Sustainable Slovakia Good Idea & $\bullet$ & - & - & & \\
\hline & $\begin{array}{l}\text { Greener Slovakia - Strategy of the Environmental } \\
\text { Policy of the Slovak Republic until } 2030\end{array}$ & & & $\bullet$ & & \\
\hline & $\begin{array}{l}\text { National BIOEAST Hub (Central and Eastern European } \\
\text { initiative for knowledge-based agriculture, } \\
\text { aquaculture and forestry in the bioeconomy) (2016) }\end{array}$ & & - & - & & \\
\hline & FSC Risk Assessment Slovakia & $\bullet$ & $\bullet$ & & & \\
\hline \multirow{10}{*}{ Sector } & $\begin{array}{c}\text { Sustainability Assessment of food and agriculture } \\
\text { systems (SAFA) }\end{array}$ & $\bullet$ & $\bullet$ & & & $\bullet$ \\
\hline & $\begin{array}{l}\text { Natural Resources Management and Environmental } \\
\text { Department of FAO }\end{array}$ & $\bullet$ & - & & & \\
\hline & Bio-based Industries & - & - & - & & \\
\hline & Global-bio-pact [95] & - & • & - & & \\
\hline & GBEP (Global Bioenergy Partnership) 2011 & - & • & - & & \\
\hline & BioSTEP 2016 & $\bullet$ & $\bullet$ & - & & \\
\hline & UNIDO Green Industry Initiative & & • & • & & \\
\hline & CSBP (Council on Sustainable Biomass Production) & - & - & - & & - \\
\hline & Sustainability of Bioeconomy (FAO*) [35] & & - & - & - & - \\
\hline & Roundtable on Sustainable Biomaterials (RSB) & $\bullet$ & $\bullet$ & - & & \\
\hline
\end{tabular}

*Food and Agriculture Organization of the United Nations

[66]). Only one study has made use of the Social Hotspots Database, which is Ekener-Petersen et al. [70]. They took into account all hotspots tagged with "high" or "very high" risk potential. Stakeholders were involved in the selection or prioritization of indicators in various approaches. Some studies arranged stakeholder workshops to analytical hierarchy processes were installed in the course of surveys, or interviews with individual experts were conducted.

\section{Prioritized Indicators by the Stakeholder-Survey}

In the following section, the results of the stakeholder surveys are presented. The survey participants were divided into two groups; the first group was comprised of "process experts" (PE), having specific knowledge about the value chain under consideration, who had the opportunity to prioritize the impact categories for all stakeholder groups. The second group was formed by various representatives $(\mathrm{R})$ of the different stakeholder groups, who had the opportunity to prioritize the impact categories for the particular stakeholder group they can represent. Figure 3 shows the ranking of the stakeholder groups as prioritized by the survey participants. The results indicate that the survey participants of both groups are in line with the literature review's results. Nearly $50 \%$ of the "process experts" and more than $30 \%$ of the "representatives" rank "workers" at the top in terms of importance to include in the SLCA. The second most frequently ranked stakeholder group is the "local community." Combining ranks 1 and 2 , the "local community" is even rated as slightly more important than "workers" by the representatives. The stakeholder categories "society" and "value chain actors" are further down in the list, and also additional stakeholder groups are of minor importance from the participants' perspective.

Subsequently, the second task in the surveys focused on the social and socioeconomic impact categories. This part of the survey was subdivided regarding the impact categories to the four respective stakeholder groups "workers," "local community," "society," and "value chain actors." Figure 4 shows the results in frequencies for the prioritization of impact categories to be included in the SLCA. For the simplicity of the graphs, the answers of process experts and representatives have been combined, and the answers given for "others" have been omitted due to low response frequencies. The survey participants were asked for their level of agreement to include the impact category into the SLCA on a six-point Likert scale from "1 not important at all" to "6 very important." The findings show that the respondents consider safe working conditions, health and safety, forced labor, fair salary as well as working hours and equal opportunities/discrimination as the most important social aspects for the stakeholder group "workers" (compare Fig. 4). Interestingly, the category child labor was ranked 


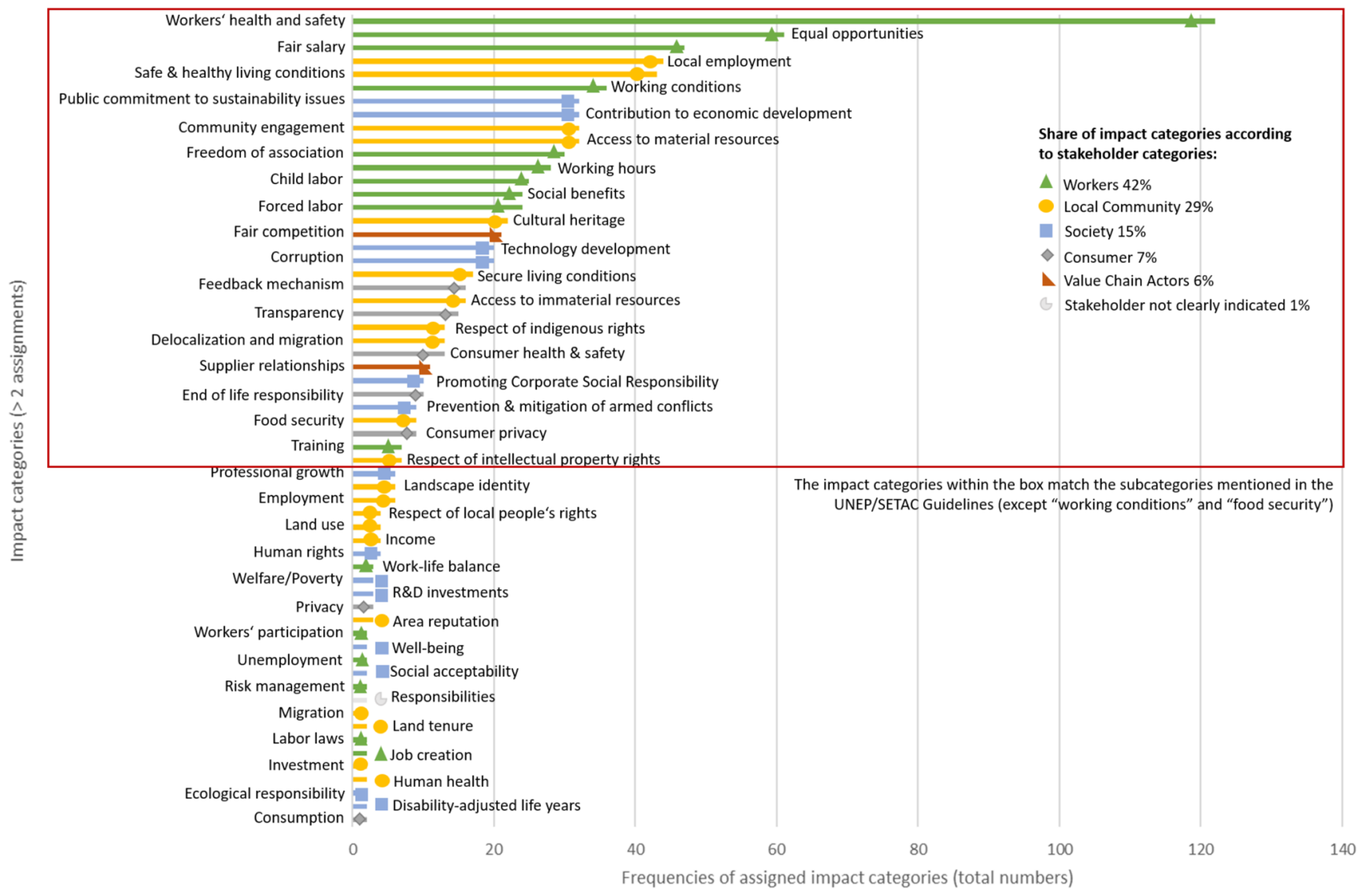

Fig. 2 Social and socioeconomic impact categories examined in the scientific publications $(n=50)$

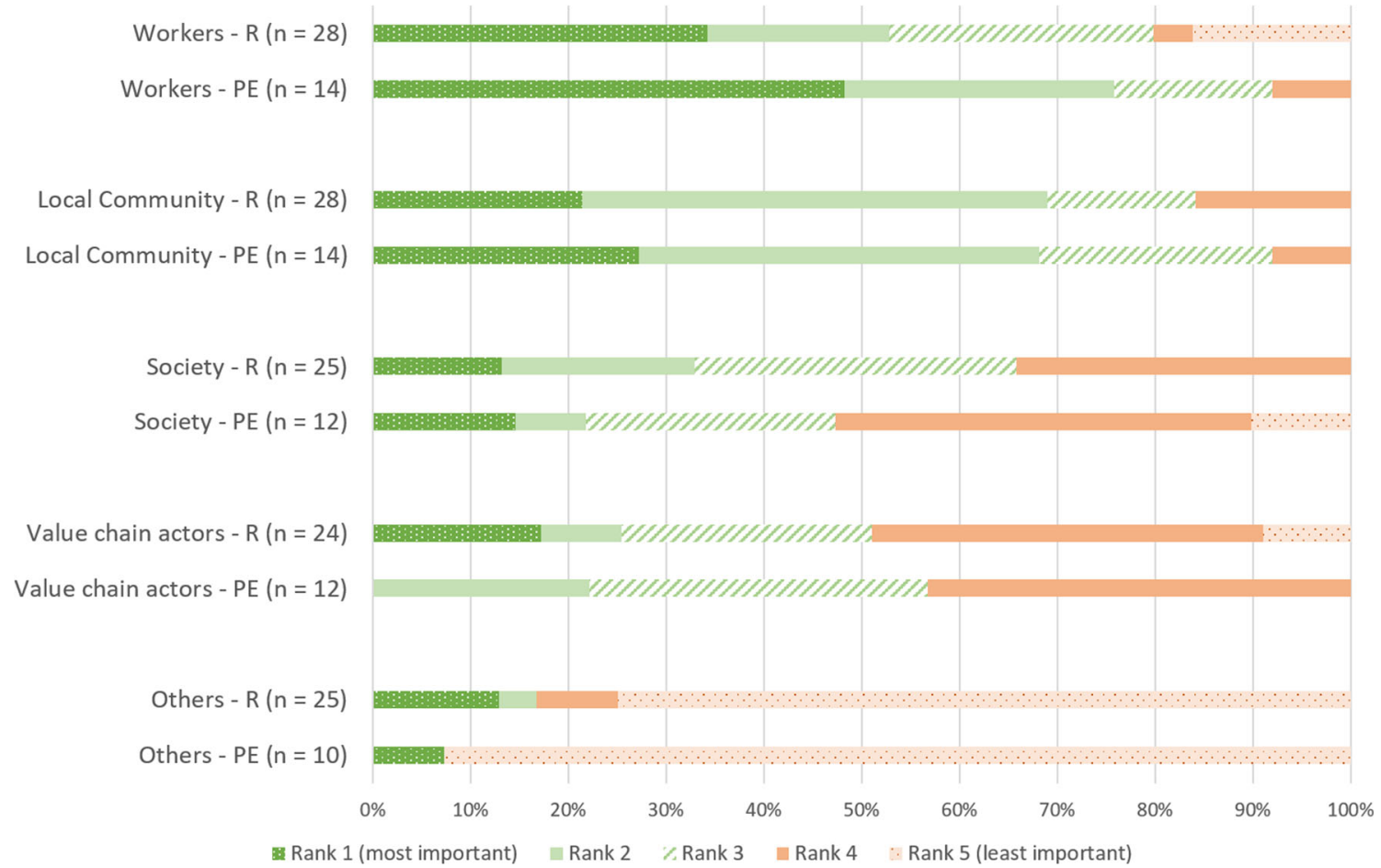

Fig. 3 Ranking of the stakeholder groups for prioritization to be included into SLCA ( $R$ representatives; $P E$ process experts) 
many times as "very important" but also received the most rankings as not important at all, especially in the representatives' survey. This may not indicate that the respondents have no problem with child labor rather than it is not a relevant aspect for Slovakia. In general, less rankings were given for "not important at all" than the rest of the scale. Only the representatives' survey shows a slight indication that they did not think it is important to include child labor and working hours in the assessment. However, working hours show a completely different picture, when the process experts and the representatives survey are compared. The frequencies for prioritization of the impact categories for the stakeholder group "local community" show that all respondents of the representatives consider the impact categories regional value creation, contribution to economic development, and local employment as "very important." Furthermore, high priority aspects are also safe and healthy living conditions, access to material resources, respect of indigenous rights/local community, and community engagement. For the group value chain actors, supplier relationships and respect of intellectual property rights are the impact categories ranked as the most important. The impact categories for the group society were generally ranked as slightly less important. However, contribution to economic development was given major priority from the representative's point of view. Discrepancies in the answers between the groups' process experts and representatives could be found for the impact category corruption. The process experts considered corruption to be far less relevant to be included into the SLCA than the representatives did. In turn, the process experts found it more important to include working hours in the SLCA than the representatives. Focusing on delocalization and migration in SLCA was more important to the process experts than for the representatives. In order to show the response behavior of the two groups in more detail, mean values and standard deviations provided in the supplementary material are shown for each impact category.

\section{Risk Mapping}

A risk mapping was carried out with the so-called Social Hotspots Database (SHDB) risk mapping tool to gather information about the country- and sector-specific risk potential. A specific sector for SRC or bio-based products industry is not included in the tool. Therefore, the sectors "crops" and "wood products" were considered as relevant for the current study. A total of eight indicators with either "high-" or "very high-" risk potential could be identified for Slovakia. The results are shown in Table 5. The consideration of indicators with "high"

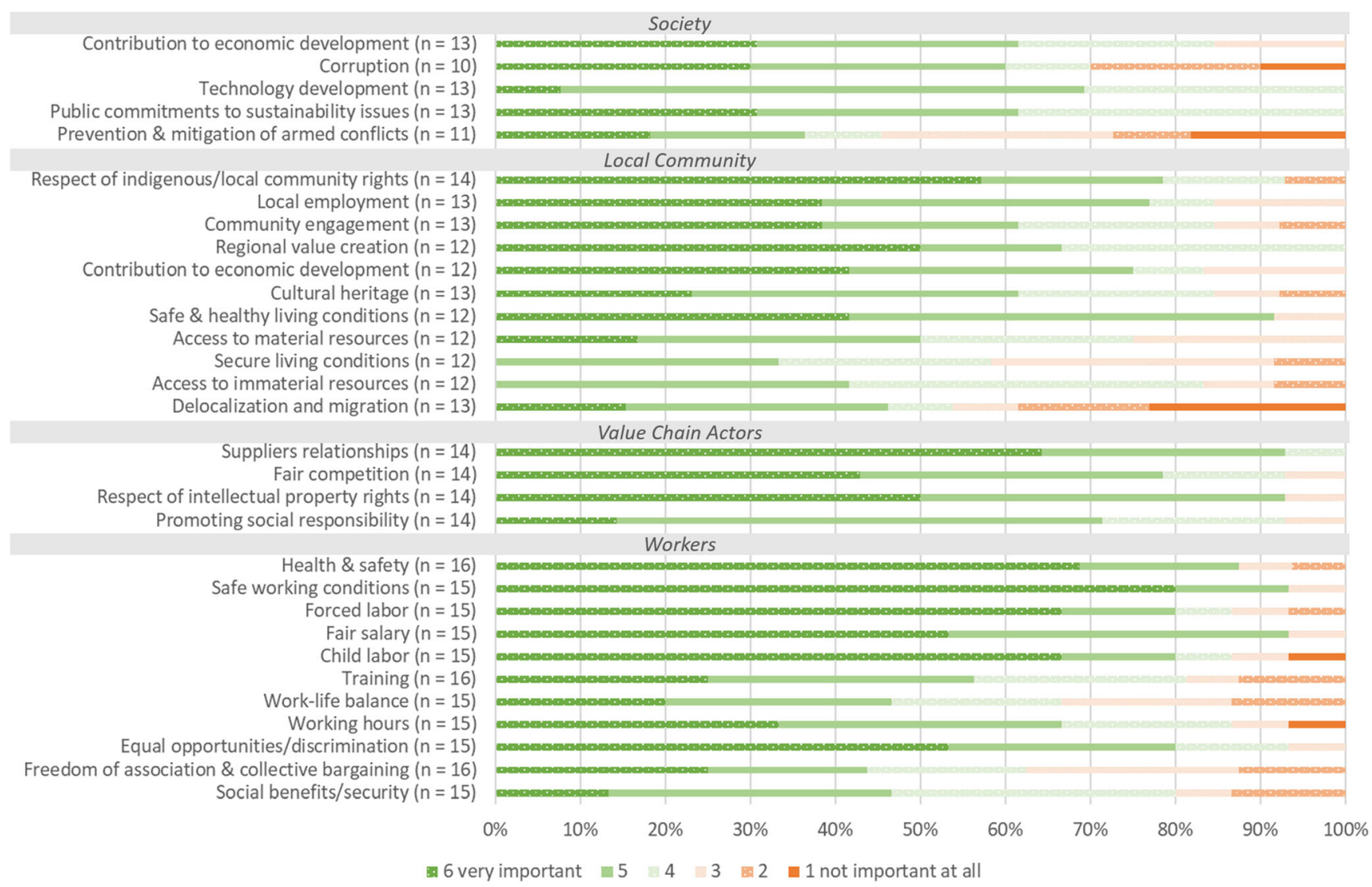

Fig. 4 Prioritization of the impact categories by the survey respondents (answers of the two groups "process experts" and "representatives" combined; the differences are shown by the help of mean values and standard deviations in the supplementary material) 
and "very high" risk potential was already found in EkenerPetersen et al. [70]. Most indicators given high priority are covering health- and safety-related issues or evidences for the working conditions.

\section{Triangulation of the Results}

By combining the results from the literature screening, from the stakeholders' surveys and the risk mapping, the most relevant social and socioeconomic impact categories should be determined. Due to the different characteristics, depending on the literature or method consulted, it is necessary to consider them on a consistent level. The results of the different methods applied in steps 1 to 3 are discussed in the following paragraphs.

Table 6 shows the triangulation of these three different steps. Considering all three approaches, strong agreement on the importance to include workers' and local communities' aspects into SLCA can be ascertained. The impact categories that were considered to be important by all three methods will be included in the assessment by respective indicators in any case. Also, the impact categories considered to be important by two methods will be included in the assessment. Furthermore, the most important categories chosen by stakeholders' engagement and risk mapping will be included in the assessment, due to their specific nature. The subsequent Table 7 demonstrates the decision on final indicators, matching the identified impact categories of interest. These indicators make it possible to measure the selected social aspects and impact categories and thus to draw conclusions about their potential positive or negative impacts. Comparing the three steps, it becomes apparent that the impact categories from the indicator screening and the stakeholder engagement are frequently consistent. The risk mapping came up with less social aspects (with high- and very high-risk potential) than the indicator screening and the stakeholder engagement. However, respect of human rights was neither covered by the indicator screening nor by the stakeholder engagement. Through the methods applied, 7 impact categories related to the stakeholder group "worker," 8 to "local community," 5 to "society," and 3 to "value chain actors" should be considered in the SLCA. Considering the described discrepancies in the availability of social impact categories and indicators for the different stakeholder groups, the results fit into this scheme.

The final set of indicators from Table 7, chosen according to feasibility, is deemed to be relevant for the SLCA of biobased products with the background of agricultural dendromass production in Eastern Slovakia. However, it must be noted that the adoption of indicators based on a single case study is doubtful [15], due to the specific factors the social impacts are related to.

\section{Discussion of the Results}

Different approaches for the selection of social aspects and indicators have been explored in order to achieve a balanced but most comprehensive picture of relevant social and socioeconomic aspects for the investigated area. The results of the different approaches are discussed in the following paragraphs.

Guidelines for SLCA The results show that the social and socioeconomic subcategories from the UNEP/SETAC Guidelines are most frequently referred to in other studies. They are widely used since their introduction in 2009 [34, $100,101]$. This picture can be also obtained by consulting the reviewed literature from Table 4 . However, the guidelines cannot guarantee a straight forward implementation, but the included social aspects and indicators can be considered as a basis for the choice of indicators. Especially "the methodological sheets for sub-categories in social life cycle assessment" from Benoît-Norris et al. [40] provide a comprehensive list of social and socioeconomic aspects and indicators. The decision on impact categories and indicators applicable to an entire value chain can be particularly challenging. As already discussed by Karlewski [88], Lehmann et al. [102], or

Table 5 SHDB indicators of "high-" and "very high-" risk potential in Slovakia

\begin{tabular}{llc}
\hline Indicator & Sector "crops" & Sector "wood products" \\
\hline Percentage of commercially owned farms & Very high risk & - \\
CIRI Human Rights Data Project & Very high risk & Very high risk \\
Malignant neoplasms, estimated age standardized & Very high risk & Very high risk \\
Average of unemployment percentage at the country level & Very high risk & Very high risk \\
Workers' remittances and compensation received & Very high risk & Very high risk \\
Non-fatal work-related injuries by sector & High risk & High risk \\
Cardiovascular diseases, estimated age standardized death rate (per 100,000) & High risk & Very high risk \\
Unemployment percentage at sector level & Low risk & Very high risk \\
\hline
\end{tabular}


Table 6 Selection of impact categories based on triangulation of the three different steps (the grey-shaded impact categories will be linked to indicators, to be able to include them in the SLCA)

\begin{tabular}{|c|c|c|c|}
\hline Impact Category & $\begin{array}{l}\text { Indicator } \\
\text { Screening } \\
\end{array}$ & $\begin{array}{c}\text { Stakeholder } \\
\text { Engagement }^{2}\end{array}$ & Risk Mapping ${ }^{3}$ \\
\hline \multicolumn{4}{|c|}{ Workers } \\
\hline Health and safety & $\mathrm{X}$ & $\mathrm{x}$ & $\mathrm{X}$ \\
\hline Equal opportunities & $\mathrm{X}$ & $\mathrm{X}$ & \\
\hline Fair salary & $\mathrm{X}$ & $\mathrm{x}$ & $\mathrm{x}$ \\
\hline Working conditions & $\mathrm{X}$ & $\mathrm{x}$ & $\mathrm{x}$ \\
\hline Freedom of association and collective bargaining & $\mathrm{X}$ & & \\
\hline Working hours & $\mathrm{X}$ & $\mathrm{X}$ & \\
\hline Child labor & $\mathrm{X}$ & $\mathrm{X}$ & \\
\hline Forced labor & $\mathrm{X}$ & $\mathrm{X}$ & \\
\hline Social benefits & $\mathrm{X}$ & & \\
\hline \multicolumn{4}{|c|}{ Local community } \\
\hline Local employment & $\mathrm{x}$ & $\mathrm{X}$ & $\mathrm{X}$ \\
\hline Safe $\&$ healthy living conditions & $\mathrm{x}$ & $\mathrm{x}$ & $\mathrm{x}$ \\
\hline Access to material resources & $\mathrm{x}$ & $\mathrm{X}$ & $\mathrm{x}$ \\
\hline Community engagement & $\mathrm{X}$ & $\mathrm{x}$ & \\
\hline Cultural heritage & $\mathrm{x}$ & $\mathrm{x}$ & \\
\hline Secure living conditions & $\mathrm{X}$ & & \\
\hline Access to immaterial resources & $\mathrm{X}$ & & \\
\hline Delocalization and migration & $\mathrm{X}$ & & \\
\hline Respect of indigenous/*local communities rights & $\mathrm{X}$ & $\mathrm{X}^{*}$ & \\
\hline Food security & $\mathrm{X}$ & & \\
\hline Regional value creation & & $\mathrm{X}$ & \\
\hline Contribution to economic development & & $\mathrm{X}$ & \\
\hline \multicolumn{4}{|c|}{ Society } \\
\hline Contribution to economic development & $\mathrm{X}$ & $\mathrm{X}$ & \\
\hline Public commitments to sustainability issues & $\mathrm{X}$ & $\mathrm{X}$ & \\
\hline Corruption & $\mathrm{X}$ & $(\mathrm{X})$ & \\
\hline Technology development & $\mathrm{X}$ & $\mathrm{x}$ & \\
\hline Prevention and mitigation of armed conflicts & $\mathrm{X}$ & & \\
\hline Respect of human rights & & & $\mathrm{x}$ \\
\hline \multicolumn{4}{|c|}{ Value chain actors } \\
\hline Fair competition & $\mathrm{X}$ & $\mathrm{X}$ & \\
\hline Supplier relationships & $\mathrm{X}$ & $\mathrm{X}$ & \\
\hline Promoting corporate social responsibility & $\mathrm{X}$ & & \\
\hline Respect of intellectual property rights & $\mathrm{x}$ & $\mathrm{X}$ & \\
\hline \multicolumn{4}{|c|}{ Consumer } \\
\hline Feedback mechanism & $\mathrm{X}$ & - & \\
\hline Transparency & $\mathrm{X}$ & - & \\
\hline Health and safety & $\mathrm{X}$ & - & \\
\hline End of life responsibility & $\mathrm{X}$ & - & \\
\hline Privacy & $\mathrm{x}$ & - & \\
\hline
\end{tabular}

$X$ indicates given high priority; - means not included; ${ }^{1}$ Top 33 of the considered impact categories, identified in the indicator screening; ${ }^{2}$ Impact categories given highest relevance (= those reaching $50 \%$ to be considered as "very important" by either one of the groups (process experts or representatives) or by both counted together; ${ }^{3}$ Impact categories referring to the indicators of "high" and "very high" risk potential from the SHDB risk mapping

Schebek and Mrani [103], this can be explained by the fact that the focus of the proposed methods lies more on an organizational than on a process level. Variations can be identified in the pre-defined stakeholder groups to be addressed in the study. It cannot be assumed that these stakeholder groups include all persons involved and must be defined more precisely for each case. In this context, the impact categories also need to be assigned to the respective stakeholder group concerned and can vary from the guidelines. ISO 14040 does not provide impact categories or indicators at all; however, an ISO-certified standard for social impact categories and indicators is missing completely. Compared to the UNEP/SETAC 
Table 7 Final set of social and socioeconomic indicators for the implementation into the SLCA

\begin{tabular}{|c|c|c|c|}
\hline Impact categories & Indicators & Units & Measurement description \\
\hline Workers' health and safety & $\begin{array}{l}\text { 1. Occupational accident rate in Slovakia } \\
\text { 2. Number of occupational (fatal) accidents } \\
\text { 3. Sick-leave days per year } \\
\text { 4. Exposure to agrochemicals }\end{array}$ & $\begin{array}{l}\% \\
\text { nb. } \\
\text { nb. } \\
\text { qual. }\end{array}$ & $\begin{array}{l}\text { 2. Number of (fatal) accidents per year, per employee } \\
\text { 3. Number of sick-leave days per year, per employee }\end{array}$ \\
\hline Equal opportunities & $\begin{array}{l}\text { 1. Country/region gender index ranking } \\
\text { 2. Presence of formal policies on equal } \\
\text { opportunities } \\
\text { 3. Rate of female workers } \\
\text { 4. Rate of workers from regional minorities }\end{array}$ & $\begin{array}{l}\text { Index } \\
\text { yes/no } \\
\% \\
\%\end{array}$ & 2. Description of potential discrimination practices \\
\hline Fair salary & $\begin{array}{l}\text { 1. Average Slovakian living wage (month) } \\
\text { 2. Average payment per month, per full-time em- } \\
\text { ployee } \\
\text { 3. Payment according to Slovakian living wage }\end{array}$ & $\begin{array}{l}€ \\
€ \\
\text { yes/no }\end{array}$ & $\begin{array}{l}\text { 3. Are all employees paid at least by the local basic } \\
\text { wage? }\end{array}$ \\
\hline Working conditions & 1. Job satisfaction & Index & Job satisfaction index \\
\hline Working hours & $\begin{array}{l}\text { 1. Contractual working hours } \\
\text { 2. Effective working hours (average) } \\
\text { 3. Effective used holidays } \\
\text { 4. Overtime compensation }\end{array}$ & $\begin{array}{l}\text { hours } \\
\text { hours } \\
\text { days } \\
\text { qual. }\end{array}$ & $\begin{array}{l}\text { 2. Hours of work per employee/day } \\
\text { 3.Hours of consumed holidays per employee/year }\end{array}$ \\
\hline Child labor & $\begin{array}{l}\text { 1. Percentage of children working by country and } \\
\text { sector } \\
\text { 2. Absence of working children under the legal } \\
\text { age }\end{array}$ & $\%$ & $\begin{array}{l}\text { 1. Description of child labor potential } \\
\text { 2. Stating names, birth dates of all workers }\end{array}$ \\
\hline Forced labor & $\begin{array}{l}\text { 1. Evidence of forced labor in the production } \\
\text { processes } \\
\text { 2. Workers voluntarily agree upon employment } \\
\text { terms }\end{array}$ & $\begin{array}{l}\text { yes/no } \\
\text { yes/no }\end{array}$ & $\begin{array}{l}\text { 2. Description of working conditions contractually } \\
\text { regulated }\end{array}$ \\
\hline Local employment & $\begin{array}{l}\text { 1. Unemployment statistics for Slovakia/region } \\
\text { 2. Percentage of workforce hired locally } \\
\text { 3. Number of local full time equivalent created } \\
\text { jobs }\end{array}$ & $\begin{array}{l}\% \\
\% \\
\text { nb. }\end{array}$ & \\
\hline $\begin{array}{l}\text { Safe and healthy living } \\
\text { conditions }\end{array}$ & $\begin{array}{l}\text { 1. Pollution levels by country } \\
\text { 2. Management effort to minimize use of } \\
\text { hazardous substances } \\
\text { 3. Food security }\end{array}$ & $\begin{array}{l}\% \\
\text { qual. } \\
\text { qual. }\end{array}$ & 3. Changes in national/local food prices \\
\hline Access to material resources & $\begin{array}{l}\text { 1. Changes in land ownership } \\
\text { 2. Infrastructure for community access developed }\end{array}$ & $\begin{array}{l}\text { yes/no } \\
\text { qual. }\end{array}$ & \\
\hline Community engagement & $\begin{array}{l}\text { 1. Number and quality of meetings with } \\
\text { community stakeholders }\end{array}$ & nb./qual. & 1. Description of community engagement activities \\
\hline Cultural heritage & $\begin{array}{l}\text { 1. Strength of policies in place to protect cultural } \\
\text { heritage } \\
\text { 2. Landscape identity }\end{array}$ & $\begin{array}{l}\text { yes/no } \\
\text { qual. }\end{array}$ & $\begin{array}{l}\text { 2. Visual attractiveness and continuity of appreciated } \\
\text { landscape heritage }[98,99]\end{array}$ \\
\hline $\begin{array}{l}\text { Respect of indigenous/local } \\
\text { communities rights }\end{array}$ & $\begin{array}{l}\text { 1. Prevalence of racial discrimination } \\
\text { 2. Local land rights conflicts/land claims } \\
\text { 3. Annual meetings held with community } \\
\text { members }\end{array}$ & $\begin{array}{l}\text { yes/no } \\
\text { yes/no } \\
\text { nb. }\end{array}$ & 2. Description of conflicts, land tenure structures, etc. \\
\hline Regional value creation & $\begin{array}{l}\text { 1. Regional value Added } \\
\text { 2. Regional investment, per unit input } \\
\text { 3. Spatial proximity of investments }\end{array}$ & $\begin{array}{l}€ \\
€ \\
\% / \text { qual. }\end{array}$ & \\
\hline $\begin{array}{l}\text { Contribution to (regional) eco- } \\
\text { nomic development* }\end{array}$ & $\begin{array}{l}\text { 1. Economic situation of country/region } \\
\text { 2. Contribution to economic progress } \\
\text { 3. Contribution to household/farm income }\end{array}$ & $\begin{array}{l}€ / \text { qual. } \\
€ / \text { qual. } \\
€ / \text { day }\end{array}$ & $\begin{array}{l}\text { 1. GDP, economic growth, unemployment rates, } \\
\text { wage level, etc. } \\
\text { 2. Revenues, paid wages, R\&D costs, etc. }\end{array}$ \\
\hline $\begin{array}{l}\text { Public commitments to } \\
\text { sustainability standards }\end{array}$ & $\begin{array}{l}\text { 1. Existence of public sustainability reporting } \\
\text { 2. Publicly available documents on agreements to } \\
\text { sustainability issues }\end{array}$ & $\begin{array}{l}\text { yes/no } \\
\text { yes/no }\end{array}$ & \\
\hline Corruption & $\begin{array}{l}\text { 1. Risk of corruption in Slovakia/the region } \\
\text { 2. Commitment to prevent corruption }\end{array}$ & $\begin{array}{l}\text { Index } \\
\text { yes/no }\end{array}$ & \\
\hline
\end{tabular}


Table 7 (continued)

\begin{tabular}{|c|c|c|c|}
\hline Impact categories & Indicators & Units & Measurement description \\
\hline & 3. Anti-corruption program carried out & yes/no & \\
\hline Technology development & $\begin{array}{l}\text { 1. Research and development costs spent } \\
\text { 2. Partnerships in R\&D }\end{array}$ & $\begin{array}{l}€ \\
\text { yes/no }\end{array}$ & 1. On organizational, sectoral, or project level \\
\hline Respect of human rights & 1. Slovakian Human Rights Index & Index & 1. CIRI Human Rights Data Project \\
\hline Fair competition & $\begin{array}{l}\text { 1. Slovakian (sectoral) law and regulations } \\
\text { 2. Involvement in and performing } \\
\text { anti-competitive business practices } \\
\text { 3. Commitment to the prevention of } \\
\text { anti-competitive behavior }\end{array}$ & $\begin{array}{l}\text { yes/no } \\
\text { yes/no } \\
\text { yes/no }\end{array}$ & $\begin{array}{l}\text { 3. e.g., through policies, strategies, formal } \\
\text { documents, etc. }\end{array}$ \\
\hline Supplier relationships & $\begin{array}{l}\text { 1. Absence of coercive communication with } \\
\text { suppliers } \\
\text { 2. On-time payments to suppliers }\end{array}$ & $\begin{array}{l}\text { yes/no } \\
\text { yes/no }\end{array}$ & \\
\hline $\begin{array}{l}\text { Respect of intellectual property } \\
\text { rights }\end{array}$ & $\begin{array}{l}\text { 1. Use of local intellectual property } \\
\text { 2. Policy and practices for compensation of using } \\
\text { local intellectual property }\end{array}$ & $\begin{array}{l}\text { yes/no } \\
\text { qual. }\end{array}$ & \\
\hline
\end{tabular}

*Contribution to economic development can be considered either from the perspective of a whole society or from the perspective of a smaller local community

Guidelines, the PSIA method does not include "society" or "value chain actors" but includes "small-scale entrepreneurs" as a separate stakeholder group. In contrast, the SEEbalance ( method adds "future generations" and "international community" as additional stakeholder groups but also leaves out "society." Social aspects regarding these additional stakeholder groups being implemented into SLCA studies could not be found by reviewing the scientific publications under consideration.

Sustainability Standards These standards can be considered as a practicable source of input regarding the relevance of social and socioeconomic aspects for an SLCA study. This was also recommended by Sureau et al. [85], who differentiated between international treaties, policy documents, and voluntary standards. The division of the standards is in turn similar to the method recommended by Siebert et al. [19], who distinguished between global, national, and sector-specific sustainability standards, which has been adopted for this purpose. Reviewing sustainability standards is not the easiest way to deal with social and socioeconomic aspects, as the results are quite extensive and from this point difficult to structure and to compare. It is questionable whether a screening of all standards is necessary, as our findings show that there are many overlaps, which was also stated by Siebert et al. [19], who identified indicators for an SLCA of a bioeconomy region in Germany. In general, a systematic review on overarching standards, including social and socioeconomic aspects, is challenging and time-consuming. However, especially regionaland sector-specific social aspects of concern can be identified on the basis of sustainability standards. As this study deals with bio-based value chains from SRC dendromass in Slovakia, a focus on regional value creation, on regional economic development, and on food security could be derived from the national and sector-specific sustainability standards. Especially regional value creation was also considered as rather important by stakeholder engagement but was rarely covered in the review of scientific publications. This underlies the importance of a tailor-made SLCA approach for studies related to bioeconomy.

Scientific Publication The publications and case studies found show, that the consultation of the UNEP/SETAC Guidelines $[8]$ is common practice. The other guidelines are barely mentioned. It can be assumed, that these guidelines are a helpful source of information, which is useful for the implementation of an SLCA. However, they do not provide any selection or prioritization of impact categories or indicators in terms of thematic (sector) or geographical context differences. Kühnen and Hahn [15] found out that the most frequently addressed impact categories in SLCA are safe and healthy living conditions, promoting social responsibility among value chain actors, consumers' health and safety, workers' health and safety, and contribution to economic development. These findings can be confirmed by our study, except that the impact category "consumers' health and safety" was not one of the most relevant aspects. Also, that workers stood out as the most frequently addressed stakeholder group, followed by local communities and society is consistent with the study of Kühnen and Hahn [15]. By the comparison of different methods, Wu et al. [34] also stated that special emphasis is laid on worker-related aspects, while those related to consumers or value chain actors are less frequently addressed.

Stakeholder Engagement We can confirm the findings from Martin et al. [16], stating that the majority of studies consider 
stakeholder perspectives for the selection on social impact categories and indicators. The main difference between conventional LCA and SLCA lies in the nature of their impact categories. In SLCA, all impact categories describe impacts influencing specific stakeholders. Therefore, the mapping of production processes, which is common practice in LCA, should be accompanied by a stakeholder mapping, to find out the stakeholders of interest within the processes of investigation. As far as the relevant stakeholders are identified, they can be involved in an SLCA study, which gives a voice to potentially affected people and helps to set the focus on the most relevant social aspects of their concern. Furthermore, the involvement of carefully selected stakeholders avoids the implementation of irrelevant indicators into an SLCA study [104]. The findings of our surveys are quite in line with the findings from the literature review. The survey participants prioritized workers' health and safety aspects and fair working conditions as well as regional value creation and opportunities for the local communities. The study of Falcone et al. [14] focuses also on social aspects for the assessment of bioeconomies and shows a strong focus of stakeholders on workers' health and safety aspects as well as on human and labor rights, which is in line with our results. Nevertheless, contribution to the economy, which can be seen as parallel to our aspect regional value creation, is not considered as one of the most important aspects. However, it must be taken into account that a non-response bias could not be considered. Additionally, a bias could arise through local surveys, as it is almost impossible to include all stakeholders [89]. The stakeholders' personal perception can have a strong influence on the results. It is recognized, that participants who benefit from the activities are very active in surveys [105]. Furthermore, a strong focus on local impacts resulted from ignoring the entire life cycle perspective [90] can also lead to a bias.

Risk Mapping Also the SHDB risk mapping shows a high relevance of health and safety aspects. These results are close to the study of Mattila et al. [90] who analyzed Finnish wood product supply chains with the SHDB. However, in contrast to the other methods tested, the indicators from the SHDB are not directly linked to specific stakeholder groups. The indicators showing a high-risk potential should raise awareness of hotspots, which should be considered for specific analysis with site-specific data $[91,106]$. This allows one to identify actual risks, since the SHDB risk mapping can only point out potential social risks [70].

The Final Set of Indicators In the selection of indicators, attention should be paid to choosing measurable, relevant $[28,107]$ and practical $[12,107]$ indicators that are sensitive to changes [12] as well as reliable and valid [107]. These selection criteria partly overlap with the benefits of triangulation, thus justifying the adoption of this method. In contrast to conventional
LCA, the quantification of impacts can become a real challenge in SLCA [69]. Therefore, qualitative indicators also have an equally important function in the SLCA [106]. As already stated, it is not always appropriate to compare different studies. However, Dewulf et al. [73] suggested indicators for raw materials production, which allow a comparison to some extent. In their study, only worker-related aspects were considered, which match the impact categories health and safety, working hours, child labor, and forced labor from our study. Another relevant study from Dale et al. [12] on socioeconomic aspects for sustainable biofuel production also considered local employment, regional value creation, and contribution to economic development as some of the most important aspects. Additionally, food security was a relevant aspect in their study; this aspect is only covered by the literature review in our study. Malkamäki et al. [108] investigated socioeconomic impacts of global large-scale tree plantations. Their findings underline the importance of an SLCA as the most frequently reported impacts were employment, land, social impacts, and livelihoods. The results indicate that it is justified to adopt a multi-methodological approach to select a balanced set of indicators for an SLCA study. Focusing on a single method bears the risk of under-representing important aspects or laying too much emphasis on less important aspects, as they are highly prevalent in literature for example.

\section{Conclusions}

The identification of relevant social aspects and the selection of appropriate indicators to assess them is the core element of every SLCA. However, little attention is given to the further development of indicator-selection-methods. The study from Siebert et al. [19], concerned with the introduction of a framework for sector- and context-specific indicator selection, was published in 2018. Our study and the findings from literature reveal that there are major differences in the nature of single studies. Differences in the geographical context, also on a micro-regional scale, in the addressing of affected stakeholders and also on sectoral levels need to be considered. Thus, the indicator-sets already established in literature are too unspecific for a direct adoption to our case study. Stakeholder participation, as suggested by several authors (e.g., Benoît et al. [8] or Siebert et al. [19]), should be stateof-the-art and is adopted in several case studies (e.g., Manik et al. [69], De Luca et al. [48], Sawaengsak et al. [65], or Rafiaani et al. [87]). The public opinion on the relevant social aspects to be included in an SLCA, plays a crucial role. Nevertheless, a generalized approach is missing, which is helpful (a) to identify the most important stakeholders, (b) how to choose the most appropriate respondents who represent the stakeholder groups best, and (c) to find a suitable standardized method to reach the respondents and capture 
their opinion. An answer to these three points would represent a major development of the SLCA method. Due to the specific issues addressed in SLCA, it is likely that this task cannot be solved by a single case study. Although conducting stakeholder involvement with an online survey has the advantage to reach a differentiated target group more easily, it is also challenging to do this without face-to-face contact. Both to explain the intention of the survey to motivate participants and also to address uncertainties, like regarding response rates or to draw conclusions on the intention of the respondents' choices, become an obstacle. If language barriers discourage from going straight into conversation, online surveys offer the possibility to overcome this barrier. In this context, it can be seen as an advantage to provide written information within the survey. Moreover, the anonymous participation encourages the respondents to answer honestly, without being afraid of any negative consequences due to their answer.

The social topics and indicators frequently discussed in literature and implemented into SLCA case studies are very close to the topics presented in the UNEP/SETAC Guidelines by Benoît et al. [8]. To base the selection of indicators purely on a literature review presupposes that the area under consideration has already been well investigated. However, more and more emphasis is given to topics that have already been applied and are thus presented as increasingly important. This is not necessarily representing the actual situation, since studies are often limited by data availability and thus, important aspects are left out. The SHDB risk mapping tool gives the possibility to get a first overview of the risks quickly. However, it is not guaranteed that the covered sectors within the tool clearly correspond to the observed case, which makes the interpretation of the results challenging. A literature review as well as the use of the risk mapping tool don't allow for adding new topics to the discussion of SLCA. Even though it is more time consuming and costly, stakeholder engagement becomes crucial for the establishment of new impact categories. To address the concerned stakeholder groups in SLCA with appropriate impact categories and indicators and to involve them in the selection of relevant impacts, require a thorough stakeholder mapping previously.

Due to the limited number of survey participants, the results of our study cannot be generalized for all bio-based value chains in Eastern Europe or even Slovakia. However, an indepth view was necessary due to the specific conditions, especially differences in the upstream processes of bio-based value chains, and in the geographical to local context. Complex value chains in the bioeconomy make it challenging to represent a complete picture of the affected stakeholders and to reach them directly or their representatives. These limitations lead to additional research topics derived from our study. For investigating relevant social aspects and indicators on a broader scope, a representative study for the Eastern European or Slovakian bioeconomy would be necessary.
However, the aforementioned differences must be considered. Nevertheless, a specific look at the selection of indicators based on regional and local characteristics and data availability will be required in any case.

Summarized, the following results can be drawn from the study on hand:

- The results show, that the consideration of the UNEP/ SETAC Guidelines has already become state-of-the-art and their subcategories cover the social aspects from the global sustainability standards widely.

- Therefore, special emphasis should be given to national and sector-specific standards.

- The screening of social aspects in scientific publications has shown that a broad range of impact categories and indicators concerning workers' health and safety and working conditions as well as local communities' employment and living conditions are available.

- Therefore, stakeholder engagement is recommended in order to not emphasize overrepresented aspects from literature only and to give the opportunity to point out underrepresented aspects.

- However, the findings of our stakeholder engagement show that the survey participants are quite in line with the findings from the literature - they prioritized workers' health and safety aspects and working conditions as well as aspects related to local communities to be included into an SLCA study. Aspects related to the stakeholder group "society" were less prioritized. Regional value creation and economic development seemed to be important aspects from the point of view of the survey participantsthis would not have been evident from literature solely.

- Therefore, it is justified to adopt a multi-methodological approach to select a balanced set of impact categories and related indicators.

The current study shows preliminary results to an SLCA study on bio-based value chains, based on wood from Short Rotation Coppice in Slovakia. The proposed indicator-set serves as a structure for data collection and helps to concentrate on relevant social and socioeconomic aspects, as a starting point for following detailed analysis. A subsequent publication will focus on the application of the indicator-set with a respective case study.

Supplementary Information The online version contains supplementary material available at https://doi.org/10.1007/s12155-021-10261-9.

Author Contribution The study conception and design were established by Daniela Fürtner, Lea Ranacher, and Franziska Hesser. Planning and implementation of the study was done by Daniela Fürtner and E. Alejandro Perdomo Echenique. Data collection was carried out by Daniela Fürtner. Data analysis and interpretation were performed by Daniela Fürtner, Lea Ranacher, and Franziska Hesser. The first draft of 
the manuscript was written by Daniela Fürtner, and all authors commented on previous versions of the manuscript. All authors read and approved the final manuscript.

Funding This study received funding from the Bio Based Industries Joint Undertaking under the European Union's Horizon 2020 research and innovation programme under grant agreement number 745874 and the Austria Research Agency (FFG) under the COMET program grant number 865905 . Open access funding provided by University of Natural Resources and Life Sciences Vienna (BOKU).

Data Availability The datasets generated and analyzed during the current study are not publicly available to guarantee the protection of confidential information but are available from the corresponding author on reasonable request.

\section{Declarations}

Ethics Approval and Consent to Participate Compliance with ethical standards was considered by informing participants about the aims and methods of the respective research project. The participation in the survey was on a voluntary basis and anonymity of the participants is preservedno inferences can be drawn from the answers to the individuals.

Conflict of Interest The authors declare no competing interests.

Open Access This article is licensed under a Creative Commons Attribution 4.0 International License, which permits use, sharing, adaptation, distribution and reproduction in any medium or format, as long as you give appropriate credit to the original author(s) and the source, provide a link to the Creative Commons licence, and indicate if changes were made. The images or other third party material in this article are included in the article's Creative Commons licence, unless indicated otherwise in a credit line to the material. If material is not included in the article's Creative Commons licence and your intended use is not permitted by statutory regulation or exceeds the permitted use, you will need to obtain permission directly from the copyright holder. To view a copy of this licence, visit http://creativecommons.org/licenses/by/4.0/.

\section{References}

1. European Union (2018) A sustainable bioeconomy for Europe: strengthening the connection between economy, society and the environment. Updated Bioeconomy Strategy. European Comission - Directorate-General for Research and Innovation, Unit F - Bioeconomy, Brussels

2. Dimitriou I, Rutz D (2015) Sustainable short rotation coppice: A handbook. WIP Renewable Energies, Munich

3. Guinée J (2016) Life cycle sustainability assessment: what is it and what are its challenges? In: Clift, Roland, A. Druckman (Eds.) Taking Stock of Industrial Ecology. Springer Open, Cham, Heidelberg, New York, Dordrecht, London, pp 45-68

4. Saurat M, Ritthoff M, Smith L (2015) Overview of existing sustainability assessment methods and tools, and of relevant standards. Deliverable 1.1., Project SAMT Sustainability Assessment Methods and Tools to Support Decision-Making in the Process Industries under Grant Agreement No. 636727. Wuppertal Institute for climate, environment and energy

5. Spierling S, Knüpffer E, Behnsen H, Mudersbach M, Krieg H, Springer S, Albrecht S, Herrmann C, Endres H-J (2018) Bio- based plastics - a review of environmental, social and economic impact assessments. J Clean Prod 185:476-491

6. Rutz D, Janssen R (2014) Socio-economic impacts of bioenergy production. Springer International Publishing, Switzerland

7. Siebert A, Bezama A, Zeug W, O'Keeffe S, Thrän D, Jähkel A (2018) RESPONSA - REgional SPezifisches cONtextualisiertes Social life cycle Assessment - Ergebnispapier "BioEconomy Cluster". Helmholtz Zentrum für Umweltforschung GmbH UFZ, Leipzig

8. Benoit C, Mazijn B, Andrews ES, Barthel L-P, Beck T, Ciroth A, Cucuzzella C, Gensch C-O, Hébert J, Lesage P, Manhart A, Mazeau P, Methot A-L, Moberg A, Norris G, Parent J, Prakash S, Reveret J-P, Spillemaeckers S, Ugaya CML, Valdivia S, Weidema B (2009) Guidelines for social life cycle assessment of products - social and socio-economic LCA guidelines complementing environmental LCA and life cycle costing, contributing to the full assessment of goods and services within the context of sustainable development. UNESP/SETAC Life Cycle Initiative, Paris

9. Goedkoop M, Indrane D, Beer ID (2018) Product social impact assessment. Methodology Report 2018, Version 1.0. PRé Sustainability, Amersfoort

10. Iofrida N, Strano A, Gulisano G, De Luca AI (2018) Why social life cycle assessment is struggling in development? Int $\mathrm{J}$ Life Cycle Assess 23(2):201-203

11. Karklina K, Slišāne D, Romagnoli F, Blumberga D (2015) Social life cycle assessment of biomethane production and distribution in Latvia. Proceedings of the 10th International Scientific and Practical Conference, Environment. Technology. Resources, Rezekne, Latvia, pp 128-132

12. Dale VH, Efroymson RA, Kline KL, Langholtz MH, Leiby PN, Oladosu GA, Davis MR, Downing ME, Hilliard MR (2013) Indicators for assessing socioeconomic sustainability of bioenergy systems: a short list of practical measures. Ecol Indic 26:87-102

13. Siebert A, Bezama A, O'Keeffe S, Thrän D (2018) Social life cycle assessment: in pursuit of a framework for assessing woodbased products from bioeconomy regions in Germany. Int J Life Cycle Assess 23(3):651-662

14. Falcone PM, González García S, Imbert E, Lijó L, Moreira MT, Tani A, Tartiu VE, Morone P (2019) Transitioning towards the bio-economy: assessing the social dimension through a stakeholder lens. Corp Soc Responsib Environ Manag 26(5):1135-1153

15. Kühnen M, Hahn R (2017) Indicators in social life cycle assessment: a review of frameworks, theories, and empirical experience. $\mathrm{J}$ Ind Ecol 21(6):1547-1565

16. Martin M, Røyne F, Ekvall T, Moberg Å (2018) Life cycle sustainability evaluations of bio-based value chains: reviewing the indicators from a Swedish perspective. Sustainability 10(547)

17. World Business Council for Sustainable Development (2008) Eco-efficiency learning module. Earthprint Ltd. ISBN: 2940240-84-1, Five Winds International, Stevenage

18. Prasara-A J, Gheewala SH, Silalertruksa T, Pongpat P, Sawaengsak W (2019) Environmental and social life cycle assessment to enhance sustainability of sugarcane-based products in Thailand. Clean Techn Environ Policy 21:1447-1458

19. Siebert A, Bezama A, O'Keeffe S, Thrän D (2018) Social life cycle assessment indices and indicators to monitor the social implications of wood-based products. J Clean Prod 172: 4074-4084

20. Macombe C, Leskinen P, Feschet P, Antikainen R (2013) Social life cycle assessment of biodiesel production at three levels: a literature review and development needs. J Clean Prod 52:205216

21. Vanclay F, Esteves AM, Aucamp I, Franks DM (2015) Social impact assessment: guidance for assessing and managing the social impacts of projects. IAIA - International Association for Impact Assessment, Fargo, ND 
22. Heink U, Kowarik I (2010) What are indicators? On the definition of indicators in ecology and environmental planning. Ecol Indic 10(3):584-593

23. Merriam-Webster (n.d.) Indicates. In: Merriam-Webster.com thesaurus. Available under .https://www.merriam-webster.com/ thesaurus/indicates. Accessed 19 May 2019

24. Petti L, Ugaya C, Maria L, Di Cesare S (2014) Systematic review of social-life cycle assessment (S-LCA) case studies. Social LCA, Montpellier (France)

25. Ekener E, Hansson J, Gustavsson M (2016) Addressing positive impacts in social LCA — discussing current and new approaches exemplified by the case of vehicle fuels. Int J Life Cycle Assess 23:556-568

26. Benoit-Norris C, Norris GA, Azuero L, Pflueger J (2019) Creating social handprints: method and case study in the electronic computer manufacturing industry. Resources 8:176

27. Norris GA (2013) The new requirement for social leadership: healing. An introduction to handprints and handprinting. In: Gröschl S (ed) Uncertainty, Diversity and The Common Good. Changing Norms and New Leadership Paradigms. Routledge, London, New York

28. Neugebauer S, Martínez-Blanco J, Scheumann R, Finkbeiner M (2015) Enhancing the practical implementation of life cycle sustainability assessment - proposal of a Tiered approach. J Clean Prod 102:165-176

29. Mathe S (2014) Integrating participatory approaches into social life cycle assessment: the SLCA participatory approach. Int $\mathbf{J}$ Life Cycle Assess 19(8):1506-1514

30. Zamani B, Sandin G, Svanström M, Peters GM (2018) Hotspot identification in the clothing industry using social life cycle assessment - opportunities and challenges of input-output modelling. Int J Life Cycle Assess 23:536-546

31. Sandin G, Peters G, Pilgård A, Svanström M, Westin M (2011) Integrating sustainability considerations into product development: a practical tool for prioritising social sustainability indicators and experiences from real case application. In: Finkbeiner ME (ed) Towards Life Cycle Sustainability Management. Springer Science + Business Media B.V., Dordrecht, Heidelberg, London, New York, pp 3-14

32. Falcone PM, Imbert E (2018) Social life cycle approach as a tool for promoting the market uptake of bio-based products from a consumer perspective. Sustainability 10(1031)

33. Rafiaani P, Kuppens T, Dael MV, Azadi H, Lebailly P, Passel SV (2018) Social sustainability assessments in the biobased economy: towards a systemic approach. Renew Sust Energ Rev 82:18391853

34. Wu R, Yang D, Chen J (2014) Social life cycle assessment revisited. Sustainability 6:4200-4226

35. Bracco S, Tani A, Çalıcıoğlu Ö, San Juan MG, Bogdanski A (2019) Indicators to monitor and evaluate the sustainability of bioeconomy. Overview and a proposed way forward. Food and Agriculture Organization of the United Nations, Rome

36. Weidema B (2014) Has ISO 14040/44 failed its role as a standard for life cycle assessment? J Ind Ecol 18(3):324-326

37. Gaduš J, Melišková I, Roháčiková O (2017) The cultivation of fast-growing trees on agricultural land in Slovakia and Czechia: legal comparison. Acta Regionalia Environ 2:45-51

38. Vásáry V, Szabó D (2018) Characteristics of sustainable bioeconomy in the CEE macro-region. Central Eur Rev Econ Finan 27(5):5-26

39. Ronzon T, Gurría P, Parisi C, Philippidis G, M'Barek R (2018) Socio-economic insights into the bioeconomy in BIOEAST countries. Research Brief. European Commission - Joint Research Centre, Seville

40. Benoit-Norris C, Traverso M, Valdivia S, Vickery-Niederman G, Franze J, Azuero L, Ciroth A, Mazijn B, Aulisio D (2013) The methodological sheets for sub-categories in social life cycle assessment (S-LCA). UNEP/SETAC Life Cycle Initiative, Paris

41. Höglmeier K, Weber-Blaschke G, Richter K (2016) Evaluation of wood cascading. In: Dewulf J, De Meester S, Alvarenga RAF (eds) Sustainability assessment of Renewables-based products: methods and case studies. John Wiley \& Sons, Ltd., Chichester

42. new earth b (2020) Social Hotspots Database. Available under. http://www.socialhotspot.org. Accessed 28 April 2020

43. ISO 14040 (2006) Environmental management - Life cycle assessment - principles and framework. International Organization for Standardization, Geneva

44. ISO 14044 (2006) International standard: environmental management - life cycle assessment - requirements and guidelines. International Organization for Standardization, Geneva

45. Goedkoop M, Indrane D, Beer ID (2019) Product social impact assessment. Handbook - 2018 Version 4.0. PRé Sustainability, Amersfoort

46. Schmidt I, Meurer M, Saling P, Kicherer A, Reuter W, Gensch CO (2004) SEEbalance ${ }^{\circledR}$ : Managing sustainability of products and processes with the socio-eco-efficiency analysis by BASF. Greener Manag Int 45:79-94

47. Franze J, Ciroth A (2011) A comparison of cut roses from Ecuador and the Netherlands. Int J Life Cycle Assess 16(4):366-379

48. De Luca AI, Molari G, Seddaiu G, Toscano A, Bombino G, Ledda L, Milani M, Vittuari M (2015) Multidisciplinary and innovative methodologies for sustainable management in agricultural systems. Environ Eng Manag J 14(7): 1571-1581

49. Vavra J, Munzarova S, Bednarikova M (2015) Assessment of social impacts of chemical and food products in the Czech Republic. In: Muthu SS (ed) Social Life Cycle Assessment. Springer Science+Business Media, Singapore, pp 147-197

50. De Luca AI, Iofrida N, Strano A, Falcone G, Gulisano G (2015) Social life cycle assessment and participatory approaches: a methodological proposal applied to citrus farming in Southern Italy. Integr Environ Assess Manag 11(3):383-396

51. Tecco N, Baudino C, Girgenti V, Peano C (2016) Innovation strategies in a fruit growers association impacts assessment by using combined LCA and s-LCA methodologies. Sci Total Environ 568:253-262

52. Arcese G, Lucchetti MC, Massa I (2017) Modeling social life cycle assessment framework for the Italian wine sector. J Clean Prod 140:1027-1036

53. Sawaengsak W, Gheewala SH (2017) Analysis of social and socio-economic impacts of sugarcane production: a case study in Nakhon Ratchasima province of Thailand. J Clean Prod 142: $1169-1175$

54. Lim CI, Biswas WK (2018) Development of triple bottom line indicators for sustainability assessment framework of Malaysian palm oil industry. Clean Techn Environ Policy 20:539-560

55. De Luca AI, Falcone G, Stillitano T, Iofrida N, Strano A, Gulisano G (2018) Evaluation of sustainable innovations in olive growing systems: a life cycle sustainability assessment case study in southern Italy. J Clean Prod 171:1187-1202

56. Prasara-A J, Gheewala HS (2018) Applying social life cycle assessment in the Thai sugar industry: challenges from the field. J Clean Prod 172:335-346

57. Petti L, Sanchez Ramirez PK, Traverso M, Ugaya CML (2018) An Italian tomato "Cuore di Bue" case study: challenges and benefits using subcategory assessment method for social life cycle assessment. Int J Life Cycle Assess 23(3):569-580

58. De Luca AI, Iofrida N, Falcone G, Stillitano T, Gulisano G (2018) Olive growing scenarios of soil management: integrating environmental, economic and social indicators from a life-cycle perspective. In: Perica S et al. (eds) Proc. VIII Int. Olive Symposium. Acta Hortic 1199, ISHS 
59. Prasara-A J, Gheewala SH (2019) Social life cycle assessment of agricultural products: experiences on rice, sugarcane and cassava in Thailand. In: Muthu SSE (ed) Social life cycle assessment. Case studies from agri and food sectors. Environmental Footprints and Eco-design of Products and Processes. Springer, Hong Kong

60. Iofrida N, De Luca AI, Silveri F, Falcone G, Stillitano T, Gulisano G, Strano A (2019) Psychosocial risk factors impact pathway for social life cycle assessment: an application to citrus life cycles in South Italy. Int J Life Cycle Assess (24):767-780

61. Du C, Ugaya C, Freire F, Dias LC, Clift R (2019) Enriching the results of screening social life cycle assessment using content analysis: a case study of sugarcane in Brazil. Int J Life Cycle Assess 24:781-793

62. Du C, Dias LC, Freire F (2019) Robust multi-criteria weighting in comparative LCA and S-LCA: a case study of sugarcane production in Brazil. J Clean Prod 218:708-717

63. Muhammad KI, Sharaai AH, Ismail MM, Harun R, Yien WS (2019) Social implications of palm oil production through social life cycle perspectives in Johor, Malaysia. Int J Life Cycle Assess 24:935-944

64. Martucci O, Arcese G, Montauti C, Acampora A (2019) Social aspects in the wine sector: comparison between social life cycle assessment and VIVA sustainable wine project indicators. Resources 8(69)

65. Sawaengsak W, Olsen SI, Hauschild MZ, Gheewala SH (2019) Development of a social impact assessment method and application to a case study of sugarcane, sugar, and ethanol in Thailand. Int J Life Cycle Assess 24:2054-2072

66. Lehmann A, Russi D, Bala A, Finkbeiner M, Fullana-i-Palmer P (2011) Integration of social aspects in decision support, based on life cycle thinking. Sustainability 3(4):562-577

67. Valente C, Spinelli R, Hillring BG (2011) LCA of environmental and socio-economic impacts related to wood energy production in alpine conditions: Valle di Fiemme (Italy). J Clean Prod 19(17): 1931-1938

68. Henke S, Theuvsen L (2013) SLCA: Regional differenzierte Bewertung von Biogasanlagen und Kurzumtriebsplantagen. Jahrb Österr Ges Agrarökonomie 23:81-90

69. Manik Y, Leahy J, Halog A (2013) Social life cycle assessment of palm oil biodiesel: a case study in Jambi Province of Indonesia. Int J Life Cycle Assess 18(7):1386-1392

70. Ekener-Petersen E, Höglund J, Finnveden G (2014) Screening potential social impacts of fossil fuels and biofuels for vehicles. Energy Policy 73:416-426

71. Weldegiorgis FS, Franks DM (2014) Social dimensions of energy supply alternatives in steelmaking: comparison of biomass and coal production scenarios in Australia. J Clean Prod 84:281-288

72. Pashaei Kamali F, Meuwissen MPM, Boer IJMD, Stolz H, Jahrl I, Garibay SV, Jacobsen R, Driesen T, Oude Lansink AGJM (2014) Identifying sustainability issues for soymeal and beef production chains. J Agric Environ Ethics 27:949-965

73. Dewulf J, Mancini L, Blengini GA, Sala S, Latunussa C, Pennington D (2015) Toward an overall analytical framework for the integrated sustainability assessment of the production and supply of raw materials and primary energy carriers. J Ind Ecol 19(6):963-977

74. Dos Santos SF, Brandi HS (2015) Model framework to construct a single aggregate sustainability indicator: an application to the biodiesel supply chain. Clean Techn Environ Policy 17:1963-1973

75. Ren J, Manzardo A, Mazzi A, Zuliani F, Scipioni A (2015) Prioritization of bioethanol production pathways in China based on life cycle sustainability assessment and multicriteria decisionmaking. Int J Life Cycle Assess 20(6):842-853

76. Sanchez Ramirez PK, Petti L, Brones F, Lie Ugaya CM (2016) Subcategory assessment method for social life cycle assessment.
Part 2: application in Natura's cocoa soap. Int J Life Cycle Assess 21:106-117

77. Contreras-Lisperguer R, Batuecas E, Mayo C, Díaz R, Pérez FJ, Springer C (2018) Sustainability assessment of electricity cogeneration from sugarcane bagasse in Jamaica. J Clean Prod (200): 390-401

78. Sajid Z, Lynch N (2018) Financial modelling strategies for social life cycle assessment: a project appraisal of biodiesel production and sustainability in Newfoundland and Labrador, Canada. Sustainability $10(9)$

79. Souza A, Watanabe MDB, Cavalett O, Lie Ugaya CM, Bonomi A (2018) Social life cycle assessment of first and second-generation ethanol production technologies in Brazil. Int J Life Cycle Assess 23:617-628

80. Collotta M, Champagne P, Tomasoni G, Alberti M, Busi L, Mabee W (2019) Critical indicators of sustainability for biofuels: an analysis through a life cycle sustainability assessment perspective. Renew Sust Energ Rev 115:109358

81. Agyekum EO, Fortuin KPJK, Harst EVD (2017) Environmental and social life cycle assessment of bamboo bicycle frames made in Ghana. J Clean Prod 143:1069-1080

82. Blanc S, Massaglia S, Brun F, Peano C, Mosso A, Giuggioli NR (2019) Use of bio-based plastics in the fruit supply chain: an integrated approach to assess environmental, economic, and social sustainability. Sustainability 11:2475

83. Cadena E, Rocca F, Gutierrez JA, Carvalho A (2019) Social life cycle assessment methodology for evaluating production process design: biorefinery case study. J Clean Prod 238:117718

84. Kolotzek C, Helbig C, Thorenz A, Reller A, Tuma A (2018) A company-oriented model for the assessment of raw material supply risks, environmental impact and social implications. J Clean Prod 176:566-580

85. Sureau S, Mazijn B, Garrido SR, Achten WMJ (2018) Social lifecycle assessment frameworks: a review of criteria and indicators proposed to assess social and socioeconomic impacts. Int J Life Cycle Assess 23(4):904-920

86. Liu KF-R, Aswara D (2019) Developing indicators based on life cycle sustainability impact assessment for strategic environmental assessment. Int J Environ Sci Dev 10(1):34-37

87. Rafiaani P, Dikopoulou Z, Van Dael M, Kuppens T, Azadi H, Lebailly P, Passel S (2020) Identifying social indicators for sustainability assessment of CCU technologies: a modified multicriteria decision making. Soc Indic Res 147:15-44

88. Karlewski H (2016) Social life cycle assessment in der Automobilindustrie, Prozesswissenschaften. Technische Universität Berlin, Berlin

89. Myllyviita T, Leskinen P, Lähtinen K, Pasanen K, Sironen S, Kähkönen T, Sikanen L (2013) Sustainability assessment of wood-based bioenergy - a methodological framework and a case-study. Biomass Bioenergy 59:293-299

90. Mattila TJ, Judl J, Macombe C, Leskinen P (2018) Evaluating social sustainability of bioeconomy value chains through integrated use of local and global methods. Biomass Bioenergy 109:276283

91. Benoit-Norris C, Cavan D Aulisio, G. Norris, Identifying social impacts in product supply chains: overview and application of the social hotspot database. Sustainability 4(2012):1946-1965

92. Webb EJ, Campbell DT, Schwartz RD, Sechrest L (1966) Unobstrusive measures: nonreactive research in the social sciences. Rand McNally \& Company, Chicago

93. Flick U (2011) Triangulation. Eine Einführung, VS Veralg für Sozialwisenschaften / Springer Fachmedien, Wiesbaden

94. Bryman A (2012) Social research methods, Fourth edn. Oxford University Press, Oxford

95. Vis M (2012) Introduction to socio-economic impact analysis. Task 3.2 Identification of socio-economic impacts of conversion 
chains from "Global Assessment of Biomass and Bioproduct Impacts on Socio-economics and Sustainability" - Project No: FP7-245085. BTG Biomass Technology Group B.V., Enschede

96. Dreyer L, Hauschild M, Schierbeck J (2010) Characterisation of social impacts in LCA. Part 1: development of indicators for labour rights. Int J Life Cycle Assess 15:247-259

97. Jørgensen A, Le Bocq A, Nazarkina L, Hauschild M (2008) Methodologies for social life cycle assessment. Int J Life Cycle Assess 13(2):96-103

98. Bakker ED, Ribeiro B, Millar K, Beekman V (2016) Actors and network activities in the bioeconomy: reflections on guidelines for participatory approaches. Deliverable 2.4., Project BioSTEP (Promoting stakeholder engagement and public awareness for a participative governance of the European bioeconomy under Grant Agreement No. 652682

99. Hasenheit M, Gerdes H, Kiresiewa Z, Beekman V (2016) Summary report on the social, economic and environmental impacts of the bioeconomy. Deliverable 2.2., Project BioSTEP (Promoting stakeholder engagement and public awareness for a participative governance of the European bioeconomy under Grant Agreement No. 652682

100. Chhipi-Shrestha GK, Hewage K, Sadiq R (2015) 'Socializing' sustainability: a critical review on current development status of social life cycle impact assessment method. Clean Techn Environ Policy 17:579-596

101. Mair-Bauernfeind C, Zimek M, Lettner M, Hesser F, Baumgartner R, Stern T (2020) Comparing the incomparable? A review of methodical aspects in the sustainability assessment of wood in vehicles. Int J Life Cycle Assess 25:2027-2049
102. Lehmann A, Zschieschang E, Traverso M, Finkbeiner M, Schebek L (2013) Social aspects for sustainability assessment of technologies-challenges for social life cycle assessment (SLCA). Int J Life Cycle Assess 18(8):1581-1592

103. Schebek L, Mrani O (2014) Environmental and sustainability assessment of biorefineries. In: Waldron K (ed) Advances in biorefineries. Biomass and waste supply chain exploitation. Woodhead Publishing, Cambridge, UK, pp 67-88

104. Lagarde V, Macombe C (2013) Designing the social life cycle of products from the systematic competitive model. Int J Life Cycle Assess 18:172-184

105. Mitchell RK, Agle BR, Wood DJ (1997) Toward a theory of stakeholder identification and salience: defining the principle of who and what really counts. Acad Manag Rev 22(4):853-886

106. Valente C, Brekke A, Modahl IS (2018) Testing environmental and social indicators for biorefineries: bioethanol and biochemical production. Int J Life Cycle Assess 23:581-596

107. Diaz-Chavez R, Vuohelainen A (2014) Test auditing of socioeconomic indicators for biofuel production. In: Rutz D, Janssen $\mathrm{R}$ (eds) Socio-economic impacts of bioenergy production. Springer International Publishing, Switzerland, pp 39-58

108. Malkamäki A, D'Amato D, Hogarth NJ, Kanninen M, Pirard R, Toppinen A, Zhou W (2018) A systematic review of the socioeconomic impacts of large-scale tree plantations, worldwide. Glob Environ Chang 53:90-103

Publisher's Note Springer Nature remains neutral with regard to jurisdictional claims in published maps and institutional affiliations. 